\title{
REVIEW
}

Open Access

\section{Overview of current adipose-derived stem cell (ADSCs) processing involved in therapeutic advancements: flow chart and regulation updates before and after COVID-19}

Loubna Mazini ${ }^{{ }^{*}}$ (D), Mohamed Ezzoubi ${ }^{2}$ and Gabriel Malka ${ }^{1}$

\begin{abstract}
Adipose-derived stem cells (ADSCS) have raised big interest in therapeutic applications in regenerative medicine and appear to fulfill the criteria for a successful cell therapy. Their low immunogenicity and their ability to selfrenew, to differentiate into different tissue-specific progenitors, to migrate into damaged sites, and to act through autocrine and paracrine pathways have been altogether testified as the main mechanisms whereby cell repair and regeneration occur. The absence of standardization protocols in cell management within laboratories or facilities added to the new technologies improved at patient's bedside and the discrepancies in cell outcomes and engraftment increase the limitations on their widespread use by balancing their real benefit versus the patient safety and security. Also, comparisons across pooled patients are particularly difficult in the fact that multiple medical devices are used and there is absence of harmonized assessment assays despite meeting regulations agencies and efficient GMP protocols. Moreover, the emergence of the COVID-19 breakdown added to the complexity of implementing standardization. Cell- and tissue-based therapies are completely dependent on the biological manifestations and parameters associated to and induced by this virus where the scope is still unknown. The initial flow chart identified for stem cell therapies should be reformulated and updated to overcome patient infection and avoid significant variability, thus enabling more patient safety and therapeutic efficiency. The aim of this work is to highlight the major guidelines and differences in ADSC processing meeting the current good manufacturing practices (cGMP) and the cellular therapy-related policies. Specific insights on standardization of ADSCs proceeding at different check points are also presented as a setup for the cord blood and bone marrow.
\end{abstract}

Keywords: ADSCS, HCT/P 351-361, ATMPs, cGMP, Standardization, COVID-19

\footnotetext{
* Correspondence: loubna.MAZINI@um6p.ma

'Laboratoire Cellules Souches et Régénération Cellulaire et Tissulaire, Center of Biological and Medical Sciences CIAM, Mohammed VI Polytechnic University (UM6P), Lot 660, Hay Moulay Rachid, 43150 Ben Guerir, Morocco Full list of author information is available at the end of the article
}

C C The Author(s). 2020 Open Access This article is licensed under a Creative Commons Attribution 4.0 International License, which permits use, sharing, adaptation, distribution and reproduction in any medium or format, as long as you give appropriate credit to the original author(s) and the source, provide a link to the Creative Commons licence, and indicate if changes were made. The images or other third party material in this article are included in the article's Creative Commons licence, unless indicated otherwise in a credit line to the material. If material is not included in the article's Creative Commons licence and your intended use is not permitted by statutory regulation or exceeds the permitted use, you will need to obtain permission directly from the copyright holder. To view a copy of this licence, visit http://creativecommons.org/licenses/by/4.0/ The Creative Commons Public Domain Dedication waiver (http://creativecommons.org/publicdomain/zero/1.0/) applies to the data made available in this article, unless otherwise stated in a credit line to the data. 


\section{Introduction}

Adipose tissue (AT) was first used as a grafting tool in plastic surgery. Freshly isolated from AT, stromal vascular fraction (SVF) was used for more suitable satisfactory tissue regeneration as it contains multipotent stem/stromal cells widely reported for their proliferative and differentiation behavior called adipose-derived stem cells (ADSCs). These cells are mesenchymal stem cells (MSCs) and were used both for their ability to differentiate into cells belonging to mesodermic, endodermic, and exodermic cellspecific lineages and for their paracrine activity [1-3]. When transplanted into damaged sites, these cells are able to interact with their adjacent microenvironment leading to the generation of new committed progenitors and cells. At the same way, they secrete exosomes containing growth factors, cytokines, chemokines, and micro-RNA involved in restoring tissue defects and biological functions [4-11]. These biomolecules play a crucial role through stimulation of the molecular mechanisms involved in angiogenesis, immunomodulation, and cell proliferation/differentiation whereby repair of damaged tissue occurs. ADSCs were reported as better immunomodulatory actors lacking MHC class II opening the way to therapeutic investigations at allogenic setting. Increasing evidences also argue that their immunomodulatory effect is related to their regenerative ability [12]. Interestingly, MSCs produced molecules with antimicrobial activity reducing pain, making them a promising tool against infections and cytokine storm [13-16]. Moreover, isolated from different origins, MSC-derived exosomes are reported efficient and promising immunomodulators in treating ill COVID-19 patients [17-28]. Altogether, these characteristics have emphasized ADSC use as an effective approach in the treatment of patients suffering from COVID-19 [14, 29, 30].

ADSCs are mainly separated from SVF using a mechanical or enzymatic process, seeded facultatively in an expansion culture before being administered through autologous or allogenic transplantation. Their use in therapeutic protocols is conditioned by high cell numbering, their low culturing passage, and reduced time delay before processing. On the other hand, their therapeutic benefit is mandatory by the proliferative potency and ability to differentiate into cell tissue of interest after administration. Nevertheless, their clinical outcomes might be hampered by viral molecules released within their exosomes complicating patient safety and security associated to the success of this cell-free therapy in regenerative medicine [31].

\section{ADSC therapeutic use: patient safety and regulatory framework}

ADSC therapy has proven efficacy and efficiency and holds great promise in regenerative medicine. Positive benefit-risk in restoring wound defects, bone regeneration, and autoimmune and neurodegenerative diseases has been reported [32-41]. However, some serious side effects have been shown such as blindness in SVF-treated patients presenting macular degeneration [42], challenging the justification of this cell therapy. Thus, patient safety and security have become the critical parameter controlling the widespread use and the bringing of stem cell-based products to the market. Actually, there are no universal guidelines for assessing a biological product, especially those classified as "nonhomologous use" [43].

To ensure patient safety and security, regulation agencies continuously modify and reinforce their approaches to regulate cellular and tissue-based products. The "human cells, tissues, or cellular or tissue-based products" $(\mathrm{HCT} / \mathrm{P})$ regulation has been set up by the Food and Drug Administration (FDA) based on two major criteria: (i) their minimal manipulation and (ii) the homologous use for the tissue-based products. Accordingly, an HCT/ $\mathrm{P}$ product meets the criteria of the regulatory requirements 21 CFR 1271 section 361 called HCT/P-361. These products do not need FDA approval for release from the facility and post-marketing thanks to the absence of other articles excepting water, crystalloids, sterilizing, or preserving agents. In addition, the HCT/P-361 regulation framework anticipates that the HCT/P should have or not have a systemic effect and a dependence upon the metabolic activity of the living cells for its primary function. They must also comply with an autologous, first- or second-degree allogenic use. Other cell and tissue products are cannot be considered lawful by the HCT/P-361 requiring thus the 21 CFR 1271 section 351 regulation and the FDA approval as a Biologics License Application (BLA). Accordingly, SVF appears to fulfill all the criteria of the HCT/P-361; however, the use of collagenase to digest AT and its presence in the separated fraction has led to its recent classification under HCT/P-351. ADSCs have been similarly classified HCT/ P-351.

To limit the processing-associated risks, several programs such as the American Association of Blood Banks (AABB), NetCord, the Foundation for the Accreditation of Cellular Therapy (FACT), and the Joint Accreditation Committee (JACIE) have drawn and designed specific accreditations to better manage the stem cell facilities and banks. In this technical aspect, these recommendations established a uniform level of practice aiming to promote high-quality products. The good tissue practice (GTP) rule proposed also under HCT/Ps rules forms the principal elements of their harmonization framework. These GTPs are intended to prevent HCT/Ps from contamination with infectious pathogens and to ensure their integrity and function through maintaining high quality and safety standards. The good manufacturing practice 
(GMP) is also designated to track and follow the level of processing and manufacturing of each cell product. However, the GMP "grade" is always thought more important for obtaining regulatory approval [44].

In Europe, the European Medicines Agency (EMA) is the authority in charge of evaluating and approving all regenerative medicine products. Their directive statutes on the advanced therapy medicinal products (ATMPs) are ensuring preclinical testing under good laboratory practice (GLP) similarly to the USA. The ATMP should meet the quality standards for intended use, traceability requirement, risk management system, and especially clinical approval to be marketed under GMP conditions.

Despite satisfying these requirements, discrepancies in the therapeutic outcomes are reported, due to the variability in medical devices and reagents used for processing and quality assessment.

\section{State of the art of the GMP requirements for ADSC use}

Widespread autologous and allogeneic ADSC use is undeniably reliable to large-scale manipulation with appropriate assurance and quality control in compliance with cGMP. High numbers of viable and functional fresh or cryopreserved ADSCs intended for clinical use are usually required. Technical and medical issues relative to the collection of tissue of origin, isolation, and storage of these cells have become thus paramount in devising the GMP conditions for future clinical use. According to the current cellular therapy regulations, ADSC preparations and derivatives should meet the GMP requirements including raw materials, clinical-grade reagents, and stem cell facilities to achieve and assure quality and safety during the entire process of preparation, banking, and manufacturing $[45,46]$.

On one side, basic cell processing methods appeared unqualified to be transferred into a cGMP facility; the whole process is considered from tissue and cell collection, manipulation, storage, and releasing to the point of care. On the other side, clinical-grade or cGMPcompatible reagents should be used for more safety in processing and testing. If not available, these reagents should be justified to prevent the potential risk of transferring immunogenic xenoproteins, infectious agents, or any other animal species leading thus the legibility of the cell product. A specific concern to highly consider is the animal-containing products deriving from animals being potentially infected or hosted by the coronavirus. Additional and rigorous actions should be performed to completely secure these products' innocuity.

Some reagents are now available on the market free from animal proteins and developed at GMP grade such as Ficoll-Paque TM PREMIUM (GE Healthcare Life Science, USA), Collagenase-NB6 (Serva Electrophoresis
GmbH, Germany), Celase ${ }^{\mathrm{Tu}}$, Adipase ${ }^{\curvearrowleft}$ or GIDzyme-2 (GID Inc), TrypLE TM Select (Inviotrogen) and TrypZean (Sigma-Aldrich), phosphate-buffered saline (PBS) and dimethyl sulfoxide (DMSO) (CliniMACS, Miltenyi Biotech, Germany), human platelet lysates PLT-Max (Mill Creek), Stemulate ${ }^{\mathrm{Tm}}$ PL-S, and Stemulate ${ }^{\mathrm{Tm}}$ PL-SP (COOK General Biotechnology).

Despite the application of HCT/P guidelines and regulations, manipulations of ADSCs and their derivatives showed many differences in their reproducibility and efficiency between laboratories and facilities and still need to be thoroughly well documented and listed according to specific standardized frameworks.

\section{SVF processing}

Defined methods were shown to harvest AT with regard to lipoaspirate's invasive manner, cell viability, and collection volume [47-49]. Figure 1 summarizes the basically steps involved in SVF and ADSC processing. After Coleman's protocol, semi-closed and completely closed systems aiming to separate fat tissue fraction from the contaminating fluids (saline solution, adrenaline, anesthetics) have been elaborated to completely secure the compelling process mandatory for clinical use. Studies have indicated that local anesthetic agents might negatively impact quantitatively and qualitatively preadipocytes [49]. Indeed, reduced ADSC viability and chondrocyte cytotoxicity were shown after lidocaine [50-52]. Ultrasound-assisted liposuction has also been reported to compromise recovery and expansion of ADSCs [53], suggesting that the absence of a standardized fat harvesting process is the first parameter leading to variability in ADSC therapeutic outcomes.

To improve SVF separation and comply with the GMP requirements, medical devices and highly technological equipment have been developed. These commercially available devices consisted usually of specific bags for washing AT and permitting the enzymatic digestion and SVF separation using at the same time clinical-grade reagent exempt from animal additives. Cell outcomes and viability added to their clonogenic potencies are reported significantly efficient compared to the control separation without preventing the variability related to the manipulator [54-57].

These devices provide all the supplies needed for the SVF separation in all-in-one single-use kit having the advantage to reduce the risk of contamination during cell separation and favoring their use at patient's bedside [58, 59]. Identical system has been used for the bone marrow (BM) with adapted perfusion system leading to expansion of BM regenerative cells [60] and MSCs [61-63].

Table 1 represents the main commercialized systems used to separate SVF in semi-automated or fully automated level. Compared to the manual methods requiring 


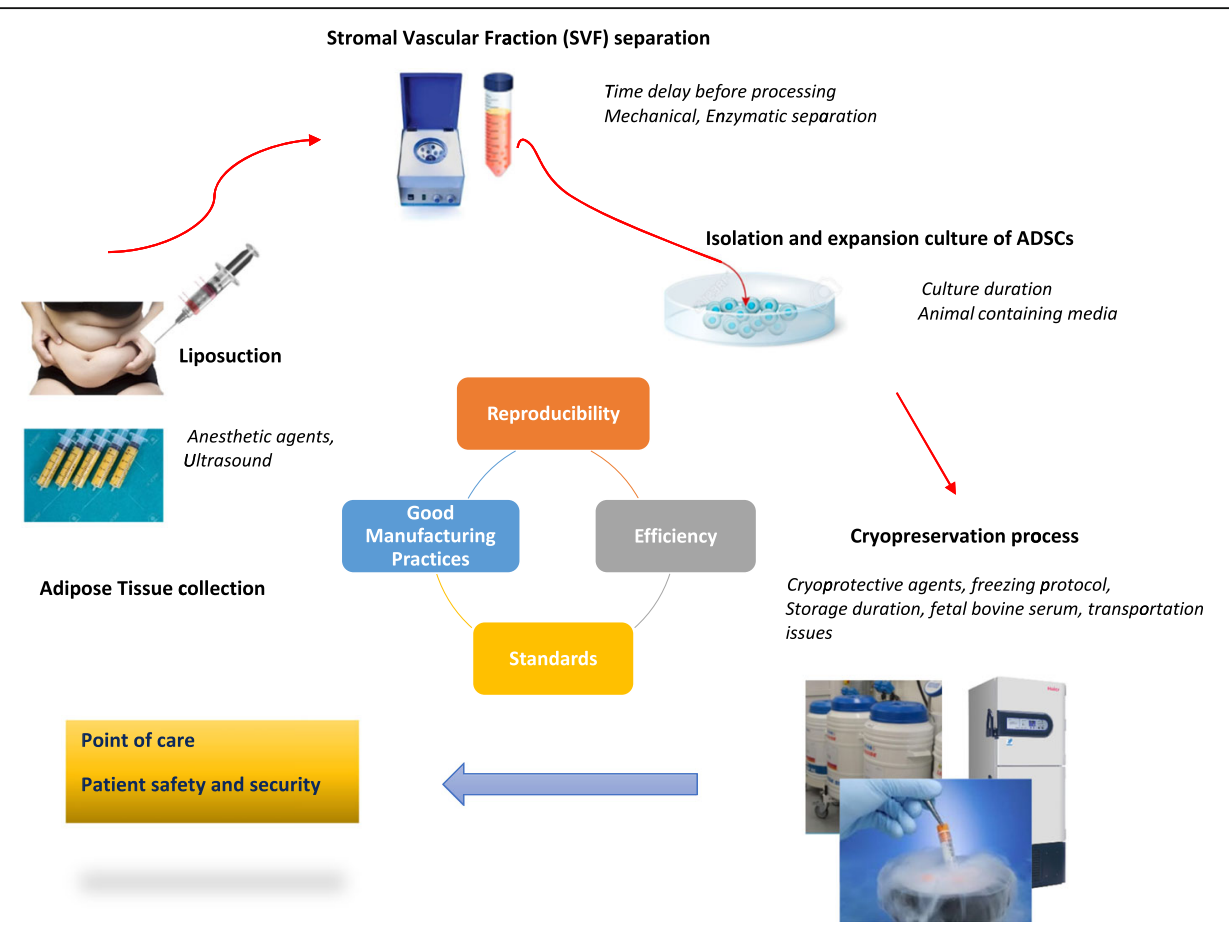

Fig. 1 Processing of adipose tissue. Lipoaspirates are collected using draining agents and undergo mechanical and/or enzymatical procedure to separate the stromal vascular fraction (SVF). ADSCS are then isolated mostly by seeding SVF in culture and expanded before releasing to the point of care. Cryopreservation ensures storage in liquid nitrogen before using in clinical issues. This manual flow chart has been improved by using allin-one single-use kits and commercialized medical devises in completely closed or semi-closed systems to meet the good manufacturing practices (GMP) requirements for therapeutic use of stem cells and derivatives

standard laboratory equipment, most of these systems allow an improvement in SVF yield process and limit the use of biosafety hood, centrifuge, and heather shaker by increasing their automation and simplifying the multiple step of the process. Semi-automated devices might need user intervention. This is completely carried out when performing the entire process in a single closed system only requiring the insertion of the lipoaspirates. However, increasing automation leads to increasing of disposable costs. Additionally, some devices are purchased with their GMP-grade proteolytic enzymes associated to their single-use kit such as the GID-SVF system (Table 1) [56, 57, 64-67]. In the same way, devices offering mechanical methods are less expensive but time consuming than those using enzymatic methods and requiring specific GMP-grade reagents and enzymes.

Table 1 also shows the higher SVF yield per gram fat for the Celurion and Icellator devices both performing enzymatic separation in a closed system with preferentially $5 \mathrm{x}$ hold more processed fat by the Celurion system associated to a higher disposable cost [57]. In addition, the Celurion 800/CRS device presents less residual enzyme levels than that observed with the Cha-Station and Lipokit systems [70] while a similar negligible residual collagenase was reported by Aronowitz et al. for the
Lipokit, GID-SVF-2, and StemSource 900/MB Celution system $[56,70]$.

Nevertheless, some findings reported automated system limitations regarding efficacy and cell outcomes [68]. However, the colony-forming unit fibroblast (CFUF) assay used as the overall indicator of the ADSC frequency and proliferation ability indicate an improved colony-forming efficiency with the GID-SVF1 method when compared to Puregraft and Stem.pras with no significance regarding the reference method [57]. CFU-F frequency was also differently reported for the Lipokit, GID-SVF-2, and the Cytori systems [56] demonstrating the existence of consistent variability within the identification of the advantageous system in terms of cellular benefit and device practicability. The absence of standardizing separation protocols performed in the different laboratories added to the complexity of the widespread use of these commercialized systems in an approved clinical use. Some systems including Station Beauty Cell, Stempia kit (N-Biotek Inc.), and Kanaka working station for SVF separation and washing (Kanaka.co.jp) are commercialized without any scientific or preclinical support and used as automated processing at patient's bedside.

Although these systems generated a significant variability of SVF regarding ADSC's profile, the GID-SVF-1, 
Table 1 Point of care devices for bed side separation of SVF

\begin{tabular}{|c|c|c|c|c|c|c|c|c|}
\hline $\begin{array}{l}\text { Medical } \\
\text { devise }\end{array}$ & Manufacturer & $\begin{array}{l}\text { Closed/ } \\
\text { semi- } \\
\text { closed }\end{array}$ & $\begin{array}{l}\text { Separation } \\
\text { method }\end{array}$ & $\begin{array}{l}\text { Proceeded fat } \\
\text { quantity (g) }\end{array}$ & $\begin{array}{l}\text { Process } \\
\text { duration } \\
\text { (min) }\end{array}$ & $\begin{array}{l}\text { Cell yield/g of fat } \\
\text { Device/control (D/C) }\end{array}$ & $\begin{array}{l}\text { Cell } \\
\text { viability } \\
\text { D/C or } \\
\text { D }\end{array}$ & References \\
\hline $\begin{array}{l}\text { Celution R } \\
\text { 800/CRS } \\
\text { StemSource } \\
900 / \mathrm{MB}\end{array}$ & $\begin{array}{l}\text { Cytori } \\
\text { Therapeutics, } \\
\text { Inc }\end{array}$ & Closed & Enzymatic & $300 \mathrm{~g}$ & 90 & $2.41 \times 10^{6} / \mathrm{NP}$ & NP & {$[57,58]$} \\
\hline $\begin{array}{l}\text { GID SVF-1, } \\
\text { SVF-2 }\end{array}$ & GID Group, Inc & Closed & Enzymatic & $300 \mathrm{~g}$ & 90 & $\begin{array}{l}0.425 \times 10^{6} \pm 0.047 \times 10^{6} / \\
0.795 \times 10^{6} \pm 0.228 \times 10^{6}\end{array}$ & $50-84 \%$ & $\begin{array}{l}{[56,57,64-} \\
67]\end{array}$ \\
\hline Icellator ${ }^{\circledast}$ & $\begin{array}{l}\text { Tissue Genesis, } \\
\text { Inc. }\end{array}$ & Closed & Enzymatic & 60 & 80 & $0.25-2.0 \times 10^{6}$ & $\begin{array}{l}64.5 \pm \\
11.4\end{array}$ & {$[57,68,69]$} \\
\hline Puregraft ${ }^{\mathrm{TM}}$ & Eurosilicone & Semi-closed & Mechanical & 250 & 100 & $\begin{array}{l}0.25 \times 10^{6} \pm 0,07 \times 10^{6} / 0.79 \times \\
10^{6} \pm 0.228 \times 10^{6}\end{array}$ & $77 \%$ & {$[57]$} \\
\hline Stem.pra ${ }^{\oplus}$ & Proteal & Closed & Mechanical & 200 & 110 & $\begin{array}{l}0.535 \times 10^{6} \pm 0.209 \times 10^{6} / \\
0.795 \times 10^{6} \pm 0.228 \times 10^{6}\end{array}$ & $69 \%$ & {$[57]$} \\
\hline Cha-Station $^{\mathrm{TM}}$ & $\begin{array}{l}\text { PNC } \\
\text { International } \\
\text { Co., Ltd. }\end{array}$ & Semi-closed & $\begin{array}{l}\text { Mechanical } \\
\text { Enzymatic }\end{array}$ & 200 & 90 & $0.05 \times 10^{6}$ & NA & {$[57,70]$} \\
\hline Sepax ${ }^{\circledast}$ & $\begin{array}{l}\text { Biosafe Grop } \\
\text { SA }\end{array}$ & Semi-closed & Mechanical & 300 & $90-120$ & $2.6 \pm 1.2 \times 10^{5} / \mathrm{ML}$ & NA & {$[55,57]$} \\
\hline UNISTATION ${ }^{\mathrm{TM}}$ & NeoGenesis & Closed & $\begin{array}{l}\text { Not } \\
\text { provided }\end{array}$ & NP & NP & $\begin{array}{l}1.1 \times 10^{5} \pm 1.1 \times 10^{5} / 2.0 \times \\
10^{5} \pm 1.7 \times 10^{5}\end{array}$ & NA & [71] \\
\hline $\begin{array}{l}\text { Lipokit } \\
\text { MaxStem }\end{array}$ & Medi-Khan's & Semi-closed & Enzymatic & NP & $88-120$ & $0.35 \times 10^{6}$ & $50-84$ & {$[56,70]$} \\
\hline
\end{tabular}

Processing with the different devices is reported regarding the closed or semi-closed systems and their efficiency to separate SVF in terms of fat quantity, cell yield and viability, and duration. These devices provide all-in-one single-use kit for the SVF separation and might also contain their GMP-grade proteolytic enzymes. NP not provided and, NA not applicable

Stem.pras, and Puregraft did not impact CD73 and HLA-ABC expression level similarly to the hematopoietic markers CD14, CD45, HLADR, and CD34 when compared to the reference method. Nevertheless, CD34 expression was drastically decreased in passage 1 expanded ADSCs [57]. Aronowitz et al. reported no significant differences in the frequency of CD31-/CD34+/CD45 cells in SVF separated by Lipokit, GID SVF-2, and StemSource 900/MB systems [56]. When using the Unistation device, SVF presented a decreased CD34+ expression frequency and an increased CD45+ cell counts with highly proliferative CD271 similar to the reference method [71]. On the other side, the Celution system reported significantly more endothelial cells and CD34/CD31 cells [70]. A recent report on the use of Icellator system demonstrated a predominant expression of CD90, CD29, and CD34 on cryopreserved SVF followed by CD45, CD105, CD73, and CD44; however, comparative analysis with a reference method was not reported [69]. Inversely, isolated by the Stem.pras method, SVF was decreased significantly in their CD90 expression level [57]. This suggests that in the absence of a comparative analysis and a standardized assessment method of the different devices, large clinical use of ATderived products associated with patient's benefit and safety meeting the international requirements remains limited. Side-by-side clinical trials will be required to establish the relevance of these differences.

\section{ADSC separation and expansion}

Different protocols were proposed in isolating ADSCs [45, 72-79]. Increasing adherent ADSCs by taking SVF to $60 \mathrm{~h}$ adhesion followed by forceful washing was also used [80]. Although sorting among specific cell markers resulted in subpopulations exhibiting distinct osteogenic and chondrogenic differentiation potentials [81, 82]. Other reports have proposed CD271 as a marker for tissue regeneration and showed that CD271+ ADSCs presented differentiation ability to mesodermic lineages [83, 84].

ADSC separation is preferentially performed by prolonged culture of the SVF mixture over time by their adherence to plastic and successive culture passages [45, 74, 77-79]. Lately, culture passages contained ADSCs populations with a stromal phenotype associated with homing properties. In contrast, early passages represented heterogeneous ADSC populations with distinct surface-cell adhesion molecules consistent with their stemness and differentiation abilities $[79,85,86]$.

Despite complying with GMP conditions, culture medium composition is a key regulator in defining cell immunophenotype and secretome composition in proteins and nucleic acids [4, 11, 54, 87]. There are 
evidences that ADSCs were primed with their microenvironment's composition highlighting the need of standardized ready-to-use culture media. Basically, culture medium is composed of Dulbecco's minimal essential medium (DMEM) supplemented with 10\% of fetal bovine serum (FBS), fetal calf serum (FCS), human platelet lysate (hPL), or growth factors derived from platelets. One of them, the fibroblast growth factor-2 (FGF-2), specifically improves chondrogenic differentiation [88] and together with FBS induced highly expression of the CD146 antigens by cultured ADSCs [87]. Using animal products containing reagents remains a real concern through their contaminating biomolecules.

These distinct properties are promising and might have important implications for the pre-selection of ADSC subpopulations and thus sibling cell-based therapies. Thus, such expanded subpopulations might be reproducibly manufactured in a time point for a clinical specific use.

Many standardized methods of isolating ADSCs have been proposed and designed, consisting of mechanical (centrifuge) or enzymatic (collagenase) means or both of them in a complete closed system [57, 75, 89-92]. These approaches aim to prevent the conventional methods associated to contamination risks and time consuming and specifically to reduce manufacturing time and costs. Indeed, these closed or semi-closed devices are effective, safe, and economic for a large clinical use and allowed for greater number of isolated and expanded ADSCs when compared to the manual procedure [76, 89, 90, 92]. The Quantum Cell Expansion System is a hollow fiber bioreactor (Terumo BCT, Lakewood, CO, USA) mostly used due to the reproducible, economical, and the large cell quantities seeded. This system is a GMP-compliant able to generate $1 \times 10^{8}$ cells in 2 weeks [93]. Similar efficient, however, manual protocols have been reported in compliance with GMP conditions [45, 76, 89].

Thoroughly, expansion protocols of ADSCs have been improved by using PL with more benefit than FBS regarding proliferation and differentiation capacities, CFUF frequency, and cell senescence [87, 94-101]. Using the Quantum Cell Expansion System, ADSCs yield estimated as population doubling is significantly more important than in control conditions with FBS [90, 92]. Also, when expanded with PL, ADSCs exhibited less immunogenic potential with a preserved normal karyotype for at least six passages of culture [102]. Likewise, evidences have been demonstrated for platelet-rich plasma (PRP) in inducing proliferation and motility of ADSCs without affecting survival of mature adipocytes improving thus fat engraftment outcomes [103]. Added to that, expansion protocols are set up for different passages and the literature showed inconsistent results. We have already reported that ADSCs should not be expanded more than 2 passages before being used or frozen [4] due to the modified immunological profile. All these factors raised the need to formulate a standard operating protocol complying with GMP requirements for extensive clinical scale.

\section{Cryopreservation and storage Freezing media}

Basically, cryopreservation could not occur without using cryoprotective agents (CPA) alone or in combination with FBS thanks to their improvement of cell viability of frozen and thawed cells. Several hydrocolloids and organic osmolytes are successfully used as CPA [52, 104-108]. Because of storage of SVF or ADSCs is usually performed with FBS, many studies aimed to develop efficient cryopreservation methods without serum and animal products to avoid immunological reactions and risk of transmission of bacterial/viral infections and prions. Xeno- and serum-free media were thus formulated objectively to be used for isolation, expansion, and banking of ADSCs. In these media, CPAs were supplemented with polymers and anti-oxidants to mimic the beneficial effects of serum [105, 109-111]. Consequently, the recovery, functionality, and multipotency of thawed ADSCs appeared fully maintained $[105,110,111]$.

However, there is evidence that the cellular activity of ADSCs after freezing and thawing was affected by CPA [112]. The most used one remains the DMSO, being reported the rare successful for all cell types even with its potential toxicity and it being difficult to remove after thawing. On the other hand, DMSO was indicated more effective than polyvinylpyrrolidone (PVP) [113] and is now manufactured at GMP and clinical grade. Likewise, cryoprotectant media containing DMSO are available on the market such as CryoStor (BioLife Solutions). Kw et al. reported an even more high cell viability and normal cell phenotype and proliferation rate of ADSCs cryopreserved in 5\% DMSO without FBS addition [114]. When adding glycerol and PL instead of FBS, high cell viability of xeno-free extracted and cryopreserved ADSCs was also demonstrated [96]. Nevertheless, despite using DMSO at clinical grade, the DMSOcontaining cryomedia are differently prepared within the laboratories, non-standardized, adding to the variability of the process.

\section{Storage duration}

ADSC use focuses on their preservation and storage possibilities; nevertheless, the optimal temperature and length of cryopreservation are particularly relevant for their cell outcomes in terms of viability and differentiation capacity [52, 104, 115-117]. For a short time (1 month), the first results did not report differences in cell viability after successive cryopreservation in $-20^{\circ} \mathrm{C}$, - 
$80^{\circ} \mathrm{C}$, and liquid nitrogen $[117,118]$. Wolter et al. suggested better conditions in $-80^{\circ} \mathrm{C}$ [115] and others favored liquid nitrogen [116]. A more recent finding indicated that ADSC viability and differentiation capabilities after 1 or 2 months cryopreservation in $-80^{\circ} \mathrm{C}$ and liquid nitrogen were comparable to fresh samples [52]. Nevertheless, few investigations are conducted for the long-term cryopreservation impact on the viability and efficiency of ADSCs. Badowski et al. have reported that ADSCs and AT lose viability and differentiation capacity after storing as long as 44 months [119].

\section{Cell outcomes}

Viability is another significant parameter reflecting cryopreservation success and it appeared closely related to the freezing rate and in some extent to thawing protocols. Indeed, post-thaw viability assessment was shown to be critical in clinical applications. Cryopreservation studies with early passages of ADSCs did not impact the immediate post-thawing viability when frozen samples were thawed at $10^{\circ} \mathrm{C} / \mathrm{min}$ in controlled rate freezer or in water bath at $37^{\circ} \mathrm{C}$ [120]. Accordingly, cryopreservation has been reported to impact ADSC functionality for longer expanded ADSCs (more than 2 passages) [4].

There are evidences that the freeze-thawing process induced cell stress manifested by necrotic activity at 4$8 \mathrm{~h}$ post-thaw and apoptotic activity after $8-12 \mathrm{~h}$ thawing, leading to a time-dependent decline in viability and function at culture temperatures [121]. The need to perform viability control at different time points of postthaw cultured cells became imminent for a more accurate assessment of cell quality and quantity. For a routine viability measurement, the trypan blue dye exclusion assay is the most commonly used. But this method is not reproducible and remains observer dependent in addition to the disadvantages of small number of cells analyzed. Many reports and consensus have suggested the use of fluorescent dyes such as 7-AAD and SYTO16 in flow cytometry analyze, as the most accurate and reliable indicators of cell viability $[121,122]$.

Also, to minimize osmotic shock, controlling thawing and transportation need to be more accurate. Some automated systems for vials and bags, such as ThawSTAR (BioCision) or VIA freeze (Asymptote), might help in standardizing the thawing process. These new solutions can be supported by the use of specific smart shippers (EVO Shipper, BioLife Solutions) in tracking positioning products during delivery.

\section{ADSC banking: adopted and emerging issues}

Umbilical cord blood (UCB) banking has previously benefited from international standards implemented by both the AABB and the FACT together with NetCord
(NetCord-FACT) for quality management systems and technical requirements. These standards are incorporated within their general cellular therapy standards, while FACT-NetCord CB requirements are separated but aligned with their cellular therapy standards. Such general guidelines and safeguards have been adopted despite the existence of heterogeneity and differences in ethical and legal process controlling the permissibility of ADSC use in therapeutics. As for the hematopoietic stem cells and $\mathrm{CB}$, storing ADSCs for long time is currently improved using cryovials or cryobags applied for manual procedures and semiclosed or closed automated systems. However, and according to GMP requirements, stem cell banks mostly used specific cryobags to allow culture and quality control procedures such as those used for freezing and banking of CB stem cells with GMP [123]. Specific containers required for storage and shipment to the point of care are mostly identical to those used in worldwide UCB banking.

Moreover, long-term banking of BM- and UCderived stem cells has become commonplace. A recent result reported that AT and ADSCs can be cryopreserved for up to 44 months until use [119]. However, the perspectives regarding cell viability, functionality, and integrity remain insufficient and further investigations are needed to act on the feasibility of the long-term banking. Likewise, in case of bacterial/viral infections, low temperatures would not stop proliferating infectious agents, suggesting that with consistent agents such as the coronavirus, sustainable quality control at different time point is becoming a real issue during cryopreservation.

\section{Product release and ADSC quality control}

Most attentions should now be focused on the inprocess controls and final release criteria including control production tests (cell dose, viability, immune phenotype, microbial, endotoxin, and mycoplasma testing) and functional assays (clonogenicity, trilineage differentiation, immunomodulation, and hematopoiesis regulation). This continuous testing process constituted an adequate tool to identify any dysfunctions leading to ADSC or derivative exclusion and prevent cell and time loss. Existing methods or tests for BMMSCs and UCB are applied according to the International Pharmacopeia and could benefit to safety evaluation of biological preparations in terms of rapidity and sensitivity such as in microbiological and endotoxin testing [124, 125]. Likewise, potency and functionality assays were largely reported in the literature despite the absence of specific markers, but standardization is still lacking. Finally, concomitant environment controls might prevent any contamination risks 
and allowed confirmation of the graft sterility before release for transplantation.

During manufacturing, ADSCs undergo different processing conditions before being administered. As indicated in Table 1, the type of devices used to separate SVF impacted directly ADSC profile. Positive cell amounts as well as cell intensity $\mathrm{CI}$ were both reported different.

ADSCs could be freshly expanded, cryopreserved/ thawed, and expanded or not. The expression of the classical mesenchymal markers CD44, CD73, CD90, and CD105 appeared to be irrespective of these manufacturing time points. Conversely, cryopreservation and 4 days ADSC expansion results on the increase of CD271- and CD63-positive cells. This non-classical MSC markers increase might correlate with increasing cell recovery during culture and their mRNA expressions differ in proliferative and post-proliferative ADSCs [126]. Additionally, some reports have indicated that ADSCs are negative for the monocyte/macrophage marker CD163 and their expression of the immune regulatory markers CD274 and CD276 could be predictive for their immunomodulatory potential [126-128]. Thus, culture conditions together with cryopreservation and the patient- or donordependent factors would impact their therapeutic outcomes and specifically their paracrine activity. ADSCs secrete largely the pro-inflammatory IL- 6 factor, and this secretion could be amplified during culture expansion [4]. Combination of flow cytometry and q-PCR techniques might be more useful in characterizing clinical-grade ADSCs and complete the first criteria previously implemented by International Society for Cell Therapy (ISCT) and International Federation for Adipose Therapeutics (IFATS) as release standard. Q-RT-PCR could also be useful for testing the apoptotic activity of thawed cells.

This characterization is of interest for tracking cell behavior during manufacturing as a biomarker for cell functionality and represents a significant concern in regulating ADSCs and derivatives. Releasing clinicalgrade ADSC should satisfy these parameters uniformly between GMP facilities Moreover, the recently reported side effects related to allogenic use of ADSCs have amplified the doubt on their relative safety for patients receiving manipulated ADSCs. Another concern not to be dismissed is that permitting transportation of ADSCs across borders might add to the complexity of the release testing, requiring thus the compliance with the regulations of the donor country and the receiving country. We have tried in Table 2 to track the route of ADSCs undergoing the three processing conditions before delivery. This might be useful in establishing criteria forward standardization to limit the biological and manufacturing variability.

\section{Limitations of ADSC-based therapy}

Spontaneous differentiation of stem cells into target cells and their migration and homing mechanisms are certainly and undeniably the tool keys in the achievement of a successful cell-based therapy. The potential benefit-to-risk in the development of ADSC therapies must be weighed and balanced at all research stages and especially during clinical translation. Functional characterization assays are evolving for a widespread

Table 2 Tracking ADSCs testing from processing to delivery to the point of care

\begin{tabular}{|c|c|c|c|c|}
\hline $\begin{array}{l}\text { Processing conditions before } \\
\text { administration }\end{array}$ & Location & $\begin{array}{l}\text { Performed actions before } \\
\text { delivery }\end{array}$ & $\begin{array}{l}\text { Proposed actions before } \\
\text { delivery }\end{array}$ & $\begin{array}{l}\text { Actions on the } \\
\text { point of care }\end{array}$ \\
\hline Separated ADSCs (autologous use) & $\begin{array}{l}\text { Patient bedside } \\
\text { Cell therapy units } \\
\text { under GLP and GCP }\end{array}$ & $\begin{array}{l}\text { Viability, cell dose } \\
\text { Functional assay (CFU-F) } \\
\text { CD73, CD90, CD105, CD34, } \\
\text { CD45, CD14, HLA-DR } \\
\text { Microbial, endotoxine, } \\
\text { mycoplasma testing }\end{array}$ & $\begin{array}{l}\text { CD271, CD274, CD276, } \\
\text { CD163, CD63 expression } \\
\text { Cytometry and q-RT-PCR }\end{array}$ & $\begin{array}{l}\text { Viability } \\
\text { Sterility apoptotic } \\
\text { activity }\end{array}$ \\
\hline $\begin{array}{l}\text { Cryopreserved and thawed (autologous } \\
\text { and allogenic use) }\end{array}$ & $\begin{array}{l}\text { Stem cell facility under } \\
\text { GMP }\end{array}$ & $\begin{array}{l}\text { Viability, cell dose } \\
\text { Functional assay (CFU-F) } \\
\text { CD73, CD90, CD105, CD34, } \\
\text { CD45, CD14, HLA-DR } \\
\text { Microbial, endotoxine, } \\
\text { mycoplasma testing }\end{array}$ & $\begin{array}{l}\text { CD271, CD274, CD276, } \\
\text { CD163, CD63 expression } \\
\text { Apoptotic activity } \\
\text { IL-6, TNF-a and IFN expres- } \\
\text { sion level (q-RT-PCR) }\end{array}$ & $\begin{array}{l}\text { Viability } \\
\text { Sterility } \\
\text { Apoptotic activity }\end{array}$ \\
\hline $\begin{array}{l}\text { Cryopreserved, thawed and expanded } \\
\text { (autologous and allogenic use) }\end{array}$ & $\begin{array}{l}\text { Stem cell facility under } \\
\text { GMP }\end{array}$ & $\begin{array}{l}\text { Viability, cell dose } \\
\text { Functional assay (CFU-F) } \\
\text { CD73, CD90, CD105, CD34, } \\
\text { CD45, CD14, HLA-DR } \\
\text { Microbial, endotoxine, } \\
\text { mycoplasma testing }\end{array}$ & $\begin{array}{l}\text { CD271, 274, CD276, CD163, } \\
\text { CD63 expression } \\
\text { Apoptotic activity } \\
\text { Karyotype } \\
\text { Migration's genes } \\
\text { IL-6, TNF-a, and IFN expres- } \\
\text { sion level (q-RT-PCR) }\end{array}$ & $\begin{array}{l}\text { Viability } \\
\text { Sterility } \\
\text { Apoptotic activity }\end{array}$ \\
\hline
\end{tabular}

ADSCs can be used after separation, cryopreservation, or cryopreservation and expansion processes. During these procedures, and regarding the medical devices used to separate SVF and ADSCs and to the stem cell facilities, variabilities in cell efficiency and clinical outcomes are observed. Continuous and standardized guidelines are proposed and reinforced through a flow chart during cell processing before delivery and in the point of care GLP good laboratory practices, GCP good cell practices, GMP good manufacturing practices 
clinical exploitation without documenting the cell type used regarding culture expansion and freezing (SVF, expanded or non-expanded ADSCs, number of expanding passage, frozen/thawed ADSCs). However, some limitations are still surrounding early-phase studies using ADSCs. Safety, purity, and application dose are the main concerns for an efficient therapeutic application at a large scale. In that fact, many reports have agreed for the presence of contaminating cell populations that may affect the targeted biological effects and induce potential side effects. The currently applied dose is about $1-5 \times$ $10^{6} \mathrm{MSCs} / \mathrm{kg}$ of body weight [129-131], but their beneficial effect might be enhanced regarding time and administration route and schedule. The heterogeneity of ADSC profile and especially the use of SVF might also impact these effects, as well as the overall ADSC physiological changes observed during expansion culture. On the other side, the absence of a specific marker did not help in characterizing and standardizing ADSC clinical investigations. However, the combination of positive and negative markers should facilitate identification and selection of a closed stromal population of CD45-CD235a-CD31CD34+ cells within SVF excluding hematopoietic and endothelial cells $[86,132,133]$. This selection should be optimized with other markers such as CD13, CD73, CD63, CD271, CD274, and CD276 for more reproducible identification or selection purposes [126, 128, 134].

Otherwise, in situ use of manipulated ADSCs is sometimes hampered by the difficulty in maintaining cell contact with the damaged tissue. Associations have emerged within latest years and used ADSCs in combination with bio-engineered materials. The most representative combination consisted of using biomaterials, growth factors, plastic support, nanostructures, polymers, etc., as a support of a tissue or organ repair based on tissue engineering [135-137]. These supports were performed to facilitate seeding of the cells and added to the difficulty in standardizing technical protocols.

In addition to the limitations already discussed [12], immunogenicity is another point of view playing a crucial role in clinical use of ADSCs. Long-term expanded ADSCs demonstrated different immunomodulatory profile. ADSC secretome is also affected by their surrounding microenvironment evidenced by differences in exosomes' composition. The latter is mainly composed of inflammatory biomolecules, suggesting that screening of potential inflammatory factors in such cells might be a pre-requisite for their use in clinical purposes.

Genetic stability after manipulation and expansion is another major issue of the advanced application of ADSCs in therapeutics. There is controversy on the spontaneous transformation of these cells potentially by the formation of mesenchymal tissues at ectopic sites $[138,139]$ or accumulation of genetic alterations and malignant transformations [140-142]; these transformations seemed unrelated to the origin of MSCs. Moreover, the extremely rare malignant events reported derived from contaminating tumor cell lines [143, 144].

Consequently, the possible undesirable differentiation of ADSCs and their interaction with tumor cells raises great interest, even if the reported cases are very limited. A quantitative approach should be intended to document the functionality of ADSCs; lineage-specific gene or protein biomarkers could be used. In addition, genetic assays should be routinely integrated through conventional/molecular karyotyping before release to the point of care.

To be administered in the point of care, ADSCs or derivatives should be transferred from the facility. Actually, no specific transportation systems are available which might impact stem cell viability and proliferation. Even if liquid nitrogen is usually used for transportation, the effect on frozen cell viability cannot be neglected. Also, DMSO is not washed in the released product, reducing thus the associated therapeutic outcomes. Chu DT et al. have reported that BM-MSCs undergo similar inconvenience; however, their non-frozen transportation is completely avoided [145]. Cell-free therapy is holding great promise through using ADSC-derived exosomes. These exosomes offer crucial benefit through (i) a consistent and standardized composition using genome editing technology, (ii) increasing their release, and (iii) new possible formulations such as lyophilizates to overcome transportation and conservation disadvantages [146].

The risks associated with the medical practice and competence are the new issues that raise serious interest across cell therapy agencies. The specialty accreditation and the participation of the national government and professional authorities in settling and standardizing policies worldwide is another issue largely studied and reported by the working group of the USA [147]. Hence, the need to overcome and control secondary side effects is actually challenging. A flow chart has been developed to identify control points at any process level which appeared different from the guidelines of finished drugs. Nevertheless, the risk tier associated to this cell therapy has been limited only to the cell products and not to the route of delivery and the practitioner as it is easily applied for the investigated new drug [147]. These contradictions might raise questions on the need to refine the stem cell therapy guidance with respect to drug manufacturing.

\section{Refining new cell-based therapies in the context of COVID-19} Evolving new approaches

The SARS-CoV-2 (severe acute respiratory syndrome coronavirus 2) breakdown is now the main interest of the 
whole world health systems. This infection is responsible of the coronavirus disease-19 so called COVID-19 and associated with a severe acute respiratory illness and multiple organ dysfunction leading to a significant mortality and a worldwide epidemic emergency. The pathogenesis of the virus is due to the presence of its angiotensin I-converting enzyme 2 receptor (ACE2), highly expressed in the lung alveolar type II cells and capillary endothelial cells $[148,149]$. Other tissues also present ACE2 such as the heart, kidney, liver, and digestive organs. Additionally, alveolar cells also express the cellular transmembrane protease serine 2 (TMPRSS2) which enable the virus entering the cell membrane through priming of its spike protein $[148,150]$. The viral infection results in an overreaction of the immune system as a cytokine storm. Overexpression and release of proinflammatory cytokines such as IL-1 $\beta$, IL-2, IL-6, interferon $\alpha$ (IFN $\alpha)$, IFN $\beta$, IFN $\gamma$, and monocyte chemoattractant protein (MCP)-1 lead to edema, air exchange dysfunction, acute respiratory distress, secondary infection, and multiple organ failure and even death $[148,151]$.

As no specific drugs or vaccines are available yet, many therapeutic plans have been proposed and most of them are supportive care rather than curative. An overview of recently investigated strategies including tackling cytokine storm, antiviral therapy, plasma from recovered patients, traditional Chinese medicine, blocking agents binding to ACE2 receptor, and vaccination have been reported [21, 152-154].

However, interesting and encouraging approaches have been realized through MSCs therapy intravenously or intrathecally administered to COVID- 19 patients $[17,21$, 23, 25, 27, 28, 148, 155-157]. Effectiveness and efficacy of MSCs in disease-associated inflammation and in immune diseases were well documented [158]. Global analysis of reduced mortality, patient safety, and absence or resolved side effects were demonstrated [21, 29]. The immunomodulatory effects of MSCs might be useful in attenuating or preventing the cytokine storm and outpace the evidence in treating infected patients by targeting immune cells including macrophages, dendritic cells, $\mathrm{T}$ and $\mathrm{B}$ cells, and natural killer. Adding to their action on immune cells, MSCs appeared to have an antimicrobial potential and acted through secretion of antimicrobial peptides and proteins (AMPs) and expression of indoleamine 2,3-dioxygenase (IDO) and IL-17, suggesting that these cells can increase the innate immune response to bacterial infection [159].

On October 12, more than 134 clinical trials are registered and 62 of them are using MSCs from different sources. Nineteen clinical trials with UC-MSCs are mostly ongoing where those performed with BM-MSCs and ADSCs (9 and 10 respectively) are not yet recruiting (http://clinicaltrials.gov). Autologous and allogenic MSC therapy has emerged as inhibiting of the immune system and thus treating COVID-19 pneumonia [13, 14, 21]. Assessing safety and efficacy of UC-MSCs in treating the pneumonia associated to the viral infection represents the major objective of these clinical trials [160-163]. UC-MSCs are also used in treating pneumonia in patients infected with coronavirus [164, 165].

First published results with infused umbilical cord MSCs (UC-MSCs) to critically ill COVID-19 patients present an improved therapeutic outcome [156, 162, 163]. Other strategies consisted of using ACE2- UC-MSCs leading to an improved pulmonary functional activity and absence of SARS-CoV-2 nucleic acid with more benefit to elderly patients [148]. Infusion of UC-MSCs leaded to a robust anti-inflammatory activity represented by an increased number of circulating lymphocytes and a decrease in overactivated cytokine-secreting immune cells and in TNF- $\alpha$ in contrary to an enhanced IL-10 secretion. MSCs were largely known to auto-induce and address their microenvironment to ensure cell proliferation and tissue regeneration. It seems that UC-MSCs act similarly through paracrine effect to counteract the cytokine storm and severe inflammation, likely by protecting or rejuvenating alveolar epithelial cells [155]. Interestingly, irradiated UC-MSCs are also expected to alleviate the symptoms associated to COVID-19 pneumonia thanks to the modulating annexin-1 released by their exosomes [166]. No comparisons between MSCs sources and clinical benefit were reported in COVID-19.

Having the advantages of being in higher quantities and easy to access, ADSCs might be further presented as a promising tool in combatting COVID-19-induced pneumonia and be a part of future treatment option. ADSCs have proven efficiencies in treating pulmonary diseases in animal models through a paracrine pathway promoting thus proliferation of epithelial cells and inhibiting apoptosis $[167,168]$. These cells were also reported to differentiate into type 2 alveolar cells [168]. One clinical trial is particularly on ADSC exosomes to explore the safety and efficiency of aerosol inhalations in the treatment of COVID-19-associated pneumonia. Thirteen severe cases of COVID-19 patients under invasive mechanical ventilation have received doses of allogenic ADSCs and presented improved clinical and biological outcomes [29]. Used at autologous and allogenic state, these cells have gained interest $[13,14,19,23,27,169]$ provided that MSCs and derivatives are performed in GMP conditions and regulated by the FDA or EMA.

\section{New cell- and tissue-based therapy limitations}

It is conceivable that ADSCs and derivatives are a great support in treating COVID-19 patients by differentiating into adipogenic and epithelial lineages, participating in immunomodulation, angiogenesis, and antiinflammatory responses, and improving cell 
regeneration. Their benefit risk still raises debate. The first criticized aspect is lung trapping as for other MSCs. However, this inconvenience is a prior advantage in treating COVID-19 patients where lung cells are infected and providing thus local immunomodulation, antiinflammation, neo-angiogenesis, and bacterial clearance [28].

The coronavirus did not infect MSC-infused cells compared to their progeny [170]; however, many criticisms should be considered to fully attain the cell therapy efficiency and patient safety. Little is known on the behavior of the patient immunity after the coronavirus infection, on the possible recurrence regarding some factor-associated patients. ACE2 receptor is widely distributed on the kidney, liver, cardiovascular and gastrointestinal organs, white and brown AT, and cultured adipocytes [171-173]. Likewise, this receptor is the key of viral tropism in AT even if no evidences of direct infection of this tissue with the SARS-CoV-2 are reported [174]. However, transplanted patients with allogeneic $\mathrm{BM}$ and renal transplants were reported positive for COVID-19 and died later probably due to the extremely lower amount of $\mathrm{T}$ cells [175]. Prior reflections and questions rise in the case of cell therapy, but at the actual knowledge, most of them remain unresolved.

i) Presence of ACE2 and TMPRSS2 or any of their variant in tissues or in cell transplant might be a potential problem; screening of their expression levels should be a pre-requisite for both the donor and receiver for the full success of cell therapy. The immune cells, bone marrow, thymus, and lymph nodes are negative for ACE2 [170];

ii) Inactivated virus or any virus fragment might live in tissues or body fluids after healing; a control quality should take part at every point of cell processing;

iii) After primary infection, the virus might lie dormant in a specific tissue and reactivate in case of frailty or decrease in immunity like the varicella zoster virus;

iv) Use of reagents containing animal components might interact with ACE2, leading to an increase of the receptor affinity to the protein $\mathrm{S}$ of the dormant virus;

v) Even if stem cell products are performed in compliance with the approved guidelines from the FDA or other specific agencies, appropriate screening relative to viability, sterility, immunological profile, paracrine activity, and virus RNA testing becomes crucial for their therapeutic use.

In the proposed treating approaches, BM-MSCs are present in very low frequencies and could not be able to repair the whole damage and perform healing of the different organs' failure. Among different stem cells, UCMSCs seem to be preferentially used in cell-based therapies conducted for infected coronavirus patients probably for immediate access [157]. Nevertheless, ADSCs are another alternative to set up new therapeutic protocols against the inflammation storm induced by the SARS-CoV-2 favoring cell repair and regeneration. On one side, the guidelines and frameworks identified for cell- and tissue-based therapies must be reformulated to answer the new fears induced by the COVID-19. On the other side, different works reported today should lead to largely repeated investigations and well-controlled trials to confirm the beneficial effect of ADSCs. These issues are challenging and control the future cell- and tissuebased therapies.

\section{Discussion}

Many clinical studies have been designed and conducted for a wide range of pathologies at autologous and allogenic settings. However, the variability of their therapeutic outcomes and lack of reproducibility are resulting from the absence of harmonization of their processing and their functional assessment balancing between patient safety and justification of the cell therapy. Some parameters play a critical role in achieving ADSC therapy and raises interest in terms of practicability and the eligibility of the products regarding the regulatory framework.

Anatomical site of AT collection is the first parameter to underlie regarding the number of suitable viable cells. Jurgens et al. demonstrated higher yields of ADSCs isolated from SVF in the abdominal subcutaneous than in the hip/thigh subcutaneous tissue [48] while these cells were negatively correlated to body mass index and independent of patient's age [176]. Nevertheless, there was increasing evidence that fat source (subcutaneous or visceral) influences the proliferation and differentiation ability of ADSCs and transplantation outcome [79, 177]. Baglioni et al. have reported a significantly higher growth rate and adipogenic potential in the abdominal subcutaneous tissue [178].

Once collected, ADSC separation still raises debates. According to the FDA guidance for human cell tissue products $(\mathrm{HCT} / \mathrm{P})$, separation of non-adipocyte cell components from fat is considered as more than "minimal manipulation." Exception could be made if only rinsing, cleansing, and sizing processing were considered, suggesting a contradictory on the SVF processing position within this regulatory. According to the EMA, ADSCs should not be cultured and isolated mechanically and used only in the subcutaneous tissue [179].

European legislation has also decided on this new advanced therapy and classified ADSCs as ATMP. Clinical use of these cells was associated to their level of substantial manipulation as a potential indicator for their functional properties [180, 181]. Uncultured or expanded 
ADSCs were not expected similar and might be dissociated in terms of phenotype and functional characteristics which have been largely demonstrated. Moreover, cell surface proteins involved in cell activity and the risk tier related to pathogen transmission raise additional considerations on the necessity of implementation of functional and viral testing during cell processing and especially for releasing to the point of care.

In contrary to basic cell processing, safety and quality testing are considered. Additional reagents might be used in the absence of clinical-grade ones but should be justified and controlled preventing thus transmission of animal infectious agents. Additionally, the animal host of the COVID-19 infection still remains unknown; screening of medium containing animal components such as animal serum, antibodies, or any recombinant protein should be a pre-requisite and certified before being on the market. More advancements are required focusing on the development of viable techniques to remove these animal components without the loss of valuable biological activity in the final product. Mostly, for FBS, current regulations and guidelines of biopharmaceutical products such as the European Medicine Agency EMEA (1793/02 of the proprietary medical products), the Pharmacopeia (Ph. $5 \mathrm{~W}$ Current edition monograph of Bovine Serum (2262), European Regulations 2005/507 for Advanced Therapies (AT), and US Code for Federal Regulation (9CFR) have recommended using of pharmagrade FBS with gamma-irradiated serum complemented with a viral test panel [45]. FBS can be replaced by PL or human serum; however, the amount of autologous serum one patient can provide is limited for a large-scale clinical expansion of ADSCs.

Another point of view to highly consider is relative to UCB collection. When pregnant women are suffering from COVID-19, it is tempting to postulate that the collected cells might not be free from viral contaminating agents and thus are not eligible for transplantation, suggesting the reinforcement of the control quality of the graft.

Another fact reinforcing the potential use of these cells is that of ADSCs can survive different freezing protocols without losing viability opening thus the way for a future large-scale cryopreservation for different therapeutic use $[120,182]$. Nevertheless, viability and functionality appeared influenced by the long-term cryopreservation. Additionally, ADSC frequency should be improved without being largely and long-term expanded preventing thus any functional change or damage [4]. Elimination of CPA during freezing and thawing could be helpful to prevent any variability in cryopreserving medium preparation and practical for widely ADSC successful clinical use.

From the point of view of quality assurance programs meeting the requirement of cGMP, a uniform cell processing protocol is of critical importance. Without standardizing, all the variables may have significant protocol differences that make cross comparisons difficult. Indeed, medical devices used for SVF separation influence directly the ADSC yield and their differentiation ability. Little reports are found on the ADSC expansion at clinical grade and a specific concern should be given on harmonizing the process and to find an international consensus for a standardizing model. The feasibility of cGMPcompliant and clinical-grade ADSC preparation and banking for clinical cell transplantations should pave the way to the harmonization of the different aspects of processing and manufacturing. Perhaps, ADSCs and derivatives in accordance with GMP standards should involve several issues similar to drug manufacturing guidelines.

In the same way, we have proposed a new flow chart to perform high numbers of ADSCs in high safety and quality standard and preventing at least the assessment variability. In the case of using uniformed medical devices within GMP facilities, it is tempting to speculate that the reproducibility of ADSC efficacy will result from these standard operating procedures. Hence, achieving their adequate clinical effect will remain patient's associated factors providing the presence of specialized practitioner. Specialty societies have followed and considered all these questions for BM and UCB transplantations leading to accreditations of stem cell banks which benefit to the manufacturing practices in different facilities operating in the field. Bringing ADSCs and derivatives into the market should take the same way.

However, and with regard to patient security, a special insight should be performed on the presence of COVID19's mRNA or derived proteins (protein S) even inactivated within the donor tissues. There are evidences arguing a viral tropism of AT and the presence of ACE2 in adipocytes [16]. Despite the promising alternative offered by using ADSCs in COVID-19, the relationship between adipocyte hypertrophy mediated by ACE2 receptors and COVID-19 might imbalance their benefit as a potential widespread therapeutic tool. Thus, viral compounds might reside or resist within AT leading to the necessity to set up viral identification from fat collection and might be during the whole processing of all stem cell-based products. Emerging strategies should take place to investigate the extent of this virus and the different ongoing vaccine testing on human tissues and on the operating procedures. Cell and tissue transplantation landscape is upset and is facing a new challenge with the SARS-CoV-2 virus breakdown.

\section{Conclusion}

ADSCs have proven efficiency in regenerating damaged tissues in vitro and in vivo. However, their self-renewal and multipotency behavior remained the focus of the success of their therapeutic use as it presents multiple 
variabilities preventing comparisons and practicability. Scientific, practitioner, and specialty societies should converge efforts on the continuously optimized parameters such as sourcing, cell dose, cryopreservation, banking, and transplantation methods altogether with functional assessments. Optimizing and standardizing new guidelines relative to this process are really challenging as the scope of the COVID-19 remains unknown.

\section{Abbreviations}

ADSCs: Adipose-derived stem cells; AT: Adipose tissue; HCT/P: Human cells, tissues, or cellular or tissue-based products; AMTPs: Advanced therapy medicinal products; BM: Bone marrow; UCB: Umbilical cord blood; GMP: Good manufacturing practices; FDA: Food and Drug Agency; CPA: Cryoprotective agent; DMSO: Dimethyl sulfoxide; FBS: Fetal bovine serum; HS: Human serum; MSCs: Mesenchymal stem cells; PBS: Phosphatebuffered saline; hPL: Human platelet lysate; SVF: Stromal vascular fraction; COVID-19: Coronavirus disease-19

\section{Acknowledgements}

The authors wish to thank Dr. Jeffrey M. Gimble for his kind assistance in providing banking stem cell information and the University Mohammed VI Polytechnic for supporting the publication.

\section{Authors' contributions}

Loubna Mazini: conception and design, collection and/or assembly of data, data analysis and interpretation, manuscript writing, final approval of manuscript. Mohamed Ezzoubi: provision of study, data analysis and interpretation. Gabriel Malka: administrative support, financial support, final approval of manuscript. The authors read and approved the final manuscript.

\section{Funding}

This work has been funded completely by the University of Mohammed VI Polytechnic, Ben Guerir, Morocco.

\section{Availability of data and materials \\ Not applicable.}

\section{Ethics approval and consent to participate}

All the authors have agreed to participate to this work.

\section{Consent for publication}

Not applicable

\section{Competing interests}

The authors declare there is no conflict of interest.

\section{Author details}

'Laboratoire Cellules Souches et Régénération Cellulaire et Tissulaire, Center of Biological and Medical Sciences CIAM, Mohammed VI Polytechnic University (UM6P), Lot 660, Hay Moulay Rachid, 43150 Ben Guerir, Morocco. ${ }^{2}$ Centre des Brûlés et chirurgie réparatrice, Centre Hospitalier Universitaire Ibn Rochd Casablanca, Faculté de Médecine et de Pharmacie Casablanca, Casablanca, Morocco.

Received: 1 July 2020 Accepted: 1 November 2020

Published online: 04 January 2021

\section{References}

1. Vermette M, Trottier V, Ménard V, Saint-Pierre L, Roy A, Fradette J. Production of a new tissue-engineered adipose substitute from human adipose-derived stromal cells. Biomaterials. 2007;28(18):2850-60.

2. Choi EW, Seo MK, Woo EY, Kim SH, Park EJ, Kim S. Exosomes from human adipose-derived stem cells promote proliferation and migration of skin fibroblasts. Exp Dermatol. 2018;27(10):1170-2.

3. Park B-S, Jang KA, Sung J-H, Park J-S, Kwon YH, Kim KJ, et al. Adiposederived stem cells and their secretory factors as a promising therapy for skin aging. Dermatol Surg. 2008;34(10):1323-6.
4. Othmani AE, Rouam S, Abbad A, Erraoui C, Harriba S, Boukind $\mathrm{H}$, et al. Cryopreservation Impacts Cell Functionality of Long Term Expanded Adipose-Derived Stem Cells. J Stem Cell Res Ther. 2019;09(01) Available from: https://www.omicsonline.org/open-access/cryopreservation-impactscell-functionality-of-long-term-expanded-adiposederived-stem-cells-21577633-1000445-107364.html. Cited 2019 Apr 19.

5. Gimble JM, Katz AJ, Bunnell BA. Adipose-derived stem cells for regenerative medicine. Circ Res. 2007;100(9):1249-60.

6. Nakagami H, Maeda K, Morishita R, Iguchi S, Nishikawa T, Takami Y, et al. Novel autologous cell therapy in ischemic limb disease through growth factor secretion by cultured adipose tissue-derived stromal cells. Arterioscler Thromb Vasc Biol. 2005;25(12):2542-7.

7. Rehman J, Traktuev D, Li J, Merfeld-Clauss S, Temm-Grove CJ, Bovenkerk JE, et al. Secretion of angiogenic and antiapoptotic factors by human adipose stromal cells. Circulation. 2004;109(10):1292-8.

8. Wang L, Tu X-H, Zhao P, Song J-X, Zou Z-D. Protective effect of transplanted bone marrow-derived mesenchymal stem cells on pancreatitisassociated lung injury in rats. Mol Med Rep. 2012;6(2):287-92.

9. Prichard HL, Reichert W, Klitzman B. IFATS collection: Adipose-derived stromal cells improve the foreign body response. Stem Cells. 2008;26(10): 2691-5.

10. Ren G, Zhang L, Zhao X, Xu G, Zhang Y, Roberts Al, et al. Mesenchymal stem cell-mediated immunosuppression occurs via concerted action of chemokines and nitric oxide. Cell Stem Cell. 2008;2(2):141-50.

11. Kilroy GE, Foster SJ, Wu X, Ruiz J, Sherwood S, Heifetz A, et al. Cytokine profile of human adipose-derived stem cells: expression of angiogenic, hematopoietic, and pro-inflammatory factors. J Cell Physiol. 2007;212(3): 702-9.

12. Mazini L, Rochette L, Admou B, Amal S, Malka G. Hopes and Limits of Adipose-Derived Stem Cells (ADSCs) and Mesenchymal Stem Cells (MSCs) in Wound Healing. Int J Mol Sci. 2020;21(4).

13. Gentile P, Sterodimas A. Adipose Stem Cells (ASCs) and Stromal Vascular Fraction (SVF) as a Potential Therapy in Combating (COVID-19)-Disease. Aging Dis. 2020;11(3):465-9.

14. Gentile P, Sterodimas A. Adipose-derived stromal stem cells (ASCs) as a new regenerative immediate therapy combating coronavirus (COVID-19)-induced pneumonia. Expert Opin Biol Ther. 2020;20(7):711-6.

15. Rogers CJ, Harman RJ, Bunnell BA, Schreiber MA, Xiang C, Wang F-S, et al. Rationale for the clinical use of adipose-derived mesenchymal stem cells for COVID-19 patients. J Transl Med. 2020;18(1):203.

16. Copcu HE. Potential Using of Fat-derived Stromal Cells in the Treatment of Active Disease, and also, in Both Pre- and Post-Periods in COVID-19. Aging Dis. 2020;11(4):730-6.

17. Bulut Ö, GÜrsel İ. Mesenchymal stem cell derived extracellular vesicles: promising immunomodulators against autoimmune, autoinflammatory disorders and SARS-CoV-2 infection. Turk J Biol = Turk Biyoloji Dergisi. 2020; 44(3):273-82.

18. Taghavi-Farahabadi M, Mahmoudi M, Soudi S, Hashemi SM. Hypothesis for the management and treatment of the COVID-19-induced acute respiratory distress syndrome and lung injury using mesenchymal stem cell-derived exosomes. Med Hypotheses. 2020;144:109865.

19. Gardin C, Ferroni L, Chachques JC, Zavan B. Could Mesenchymal Stem CellDerived Exosomes Be a Therapeutic Option for Critically III COVID-19 Patients? J Clin Med. 2020;9(9).

20. Pinky null, Gupta S, Krishnakumar V, Sharma Y, Dinda AK, Mohanty S. Mesenchymal Stem Cell Derived Exosomes: a Nano Platform for Therapeutics and Drug Delivery in Combating COVID-19. Stem Cell Rev Rep. 2020.

21. Qu W, Wang Z, Hare JM, Bu G, Mallea JM, Pascual JM, et al. Cell-based therapy to reduce mortality from COVID-19: Systematic review and metaanalysis of human studies on acute respiratory distress syndrome. Stem Cells Transl Med. 2020;9(9):1007-22.

22. Jayaramayya K, Mahalaxmi I, Subramaniam MD, Raj N, Dayem AA, Lim KM, et al. Immunomodulatory effect of mesenchymal stem cells and mesenchymal stem-cell-derived exosomes for COVID-19 treatment. BMB Rep. 2020;53(8):400-12.

23. Deffune E, Prudenciatti A, Moroz A. Mesenchymal stem cell (MSC) secretome: A possible therapeutic strategy for intensive-care COVID-19 patients. Med Hypotheses. 2020;142:109769.

24. Elrashdy F, Aljaddawi AA, Redwan EM, Uversky VN. On the potential role of exosomes in the COVID-19 reinfection/reactivation opportunity. J Biomol Struct Dyn. 2020:1-12. 
25. Tsuchiya A, Takeuchi S, Iwasawa T, Kumagai M, Sato T, Motegi S, et al. Therapeutic potential of mesenchymal stem cells and their exosomes in severe novel coronavirus disease 2019 (COVID-19) cases. Inflamm Regen. 2020;40:14.

26. A B, Z P, N B, M H, A S, N R. Regenerative Medicine in COVID-19 Treatment: Real Opportunities and Range of Promises. Stem Cell Rev Rep. 2020; Available from: https://pubmed.ncbi.nlm.nih.gov/32564256/. Cited 2020 Oct 6

27. Gupta A, Kashte S, Gupta M, Rodriguez HC, Gautam SS, Kadam S. Mesenchymal stem cells and exosome therapy for COVID-19: current status and future perspective. Hum Cell. 2020;33(4):907-18.

28. Bari E, Ferrarotti I, Saracino L, Perteghella S, Torre ML, Corsico AG. Mesenchymal Stromal Cell Secretome for Severe COVID-19 Infections: Premises for the Therapeutic Use. Cells. 2020;9(4).

29. Sánchez-Guijo F, García-Arranz M, López-Parra M, Monedero P, MataMartínez C, Santos A, et al. Adipose-derived mesenchymal stromal cells for the treatment of patients with severe SARS-CoV-2 pneumonia requiring mechanical ventilation. A proof of concept study. EClinicalMedicine. 2020; 25:100454.

30. Schäfer R, Spohn G, Bechtel M, Bojkova D, Baer PC, Kuçi S, et al. Human Mesenchymal Stromal Cells Are Resistant to SARS-CoV-2 Infection under Steady-State, Inflammatory Conditions and in the Presence of SARS-CoV-2Infected Cells. Stem Cell Rep. 2020.

31. Gunasekaran M, Bansal S, Ravichandran R, Sharma M, Perincheri S, Rodriguez $F$, et al. Respiratory viral infection in lung transplantation induces exosomes that trigger chronic rejection. J Heart Lung Transplant. 2020;39(4):379-88.

32. Widgerow AD, Salibian AA, Lalezari S, Evans GRD. Neuromodulatory nerve regeneration: adipose tissue-derived stem cells and neurotrophic mediation in peripheral nerve regeneration. J Neurosci Res. 2013;91(12):1517-24.

33. Assunção-Silva RC, Mendes-Pinheiro B, Patrício $P$, Behie LA, Teixeira FG, Pinto $L$, et al. Exploiting the impact of the secretome of MSCs isolated from different tissue sources on neuronal differentiation and axonal growth. Biochimie. 2018;155:83-91.

34. Im G-I. Regeneration of articular cartilage using adipose stem cells. J Biomed Mater Res A. 2016;104(7):1830-44.

35. Gonzalez-Rey E, Gonzalez MA, Varela N, O'Valle F, Hernandez-Cortes P, Rico $L$, et al. Human adipose-derived mesenchymal stem cells reduce inflammatory and T cell responses and induce regulatory T cells in vitro in rheumatoid arthritis. Ann Rheum Dis. 2010;69(1):241-8.

36. Pak J, Lee JH, Pak N, Pak Y, Park KS, Jeon JH, et al. Cartilage Regeneration in Humans with Adipose Tissue-Derived Stem Cells and Adipose Stromal Vascular Fraction Cells: Updated Status. Int J Mol Sci. 2018;19(7).

37. Charles-de-Sá L, Gontijo-de-Amorim NF, Maeda Takiya C, Borojevic R, Benati $D$, Bernardi $P$, et al. Antiaging treatment of the facial skin by fat graft and adipose-derived stem cells. Plast Reconstr Surg. 2015;135(4):999-1009.

38. Koh KS, Oh TS, Kim H, Chung IW, Lee KW, Lee HB, et al. Clinical application of human adipose tissue-derived mesenchymal stem cells in progressive hemifacial atrophy (Parry-Romberg disease) with microfat grafting techniques using 3-dimensional computed tomography and 3-dimensional camera. Ann Plast Surg. 2012;69(3):331-7.

39. Rigotti G, Charles-de-Sá L, Gontijo-de-Amorim NF, Takiya CM, Amable PR, Borojevic R, et al. Expanded Stem Cells, Stromal-Vascular Fraction, and Platelet-Rich Plasma Enriched Fat: Comparing Results of Different Facial Rejuvenation Approaches in a Clinical Trial. Aesthet Surg J. 2016; 36(3):261-70

40. Stepien A, Dabrowska NL, Maciagowska M, Macoch RP, Zolocinska A, Mazur S, et al. Clinical Application of Autologous Adipose Stem Cells in Patients with Multiple Sclerosis: Preliminary Results. Mediat Inflamm. 2016;2016: 5302120 .

41. Fang $B$, Song $Y$, Liao $L$, Zhang $Y$, Zhao RC. Favorable response to human adipose tissue-derived mesenchymal stem cells in steroid-refractory acute graft-versus-host disease. Transplant Proc. 2007;39(10):3358-62.

42. Kuriyan AE, Albini TA, Townsend JH, Rodriguez M, Pandya HK, Leonard RE, et al. Vision Loss after Intravitreal Injection of Autologous "Stem Cells" for AMD. N Engl J Med. 2017;376(11):1047-53.

43. Sakai D, Schol J, Foldager CB, Sato M, Watanabe M. Regenerative technologies to bed side: Evolving the regulatory framework. J Orthop Translat. 2017;9:1-7.

44. Who. Handbook: Good Laboratory Practice (GLP): Quality Practices for Regulated Non-clinical Research and Development. Geneva; Herndon: World Health Organization Stylus Publishing, LLC [distributor; 2010. Available from: http://public.ebookcentral.proquest.com/choice/publicfullrecord.aspx?p= 579101. Cited 2020 May 4.

45. Larijani B, Aghayan H, Goodarzi P, Mohamadi-Jahani F, Norouzi-Javidan A, Dehpour AR, et al. Clinical Grade Human Adipose Tissue-Derived Mesenchymal Stem Cell Banking. Acta Med Iran. 2015;53(9):540-6.

46. Bieback K, Hecker A, Kocaömer A, Lannert $H$, Schallmoser K, Strunk D, et al. Human alternatives to fetal bovine serum for the expansion of mesenchymal stromal cells from bone marrow. Stem Cells. 2009;27(9): 2331-41.

47. Aguena M, Fanganiello RD, Tissiani LAL, Ishiy FAA, Atique R, Alonso N, et al. Optimization of parameters for a more efficient use of adipose-derived stem cells in regenerative medicine therapies. Stem Cells Int. 2012;2012: 303610 .

48. Jurgens WJFM, Oedayrajsingh-Varma MJ, Helder MN, Zandiehdoulabi B, Schouten TE, Kuik DJ, et al. Effect of tissue-harvesting site on yield of stem cells derived from adipose tissue: implications for cell-based therapies. Cell Tissue Res. 2008:332(3):415-26.

49. Keck M, Zeyda M, Gollinger K, Burjak S, Kamolz L-P, Frey M, et al. Local anesthetics have a major impact on viability of preadipocytes and their differentiation into adipocytes. Plast Reconstr Surg. 2010;126(5):1500-5.

50. Breu A, Eckl S, Zink W, Kujat R, Angele P. Cytotoxicity of local anesthetics on human mesenchymal stem cells in vitro. Arthroscopy. 2013;29(10):1676-84.

51. Girard A-C, Atlan M, Bencharif K, Gunasekaran MK, Delarue P, Hulard O, et al. New insights into lidocaine and adrenaline effects on human adipose stem cells. Aesthet Plast Surg. 2013;37(1):144-52.

52. Roato I, Alotto D, Belisario DC, Casarin S, Fumagalli M, Cambieri I, et al. Adipose Derived-Mesenchymal Stem Cells Viability and Differentiating Features for Orthopaedic Reparative Applications: Banking of Adipose Tissue. Stem Cells Int. 2016;2016:4968724.

53. Oedayrajsingh-Varma MJ, van Ham SM, Knippenberg M, Helder MN, KleinNulend J, Schouten TE, et al. Adipose tissue-derived mesenchymal stem cell yield and growth characteristics are affected by the tissue-harvesting procedure. Cytotherapy. 2006;8(2):166-77.

54. Agostini F, Rossi FM, Aldinucci D, Battiston M, Lombardi E, Zanolin S, et al. Improved GMP compliant approach to manipulate lipoaspirates, to cryopreserve stromal vascular fraction, and to expand adipose stem cells in xeno-free media. Stem Cell Res Ther. 2018;9(1):130.

55. Güven S, Karagianni M, Schwalbe M, Schreiner S, Farhadi J, Bula S, et al. Validation of an automated procedure to isolate human adipose tissuederived cells by using the Sepax ${ }^{\circledast}$ technology. Tissue Eng Part C Methods. 2012;18(8):575-82.

56. Aronowitz JA, Lockhart RA, Hakakian CS, Birnbaum ZE. Adipose Stromal Vascular Fraction Isolation: A Head-to-Head Comparison of 4 Cell Separation Systems \#2. Ann Plast Surg. 2016;77(3):354-62.

57. Rodriguez J, Pratta A-S, Abbassi N, Fabre H, Rodriguez F, Debard C, et al. Evaluation of Three Devices for the Isolation of the Stromal Vascular Fraction from Adipose Tissue and for ASC Culture: A Comparative Study. Stem Cells Int. 2017;2017:9289213.

58. Duckers HJ, Pinkernell K, Milstein AM, Hedrick MH. The Bedside Celution system for isolation of adipose derived regenerative cells. Eurolntervention. 2006;2(3):395-8.

59. Katz AJ, Hedrick MH, Llull R, Futrell JW. A novel device for the simple and efficient refinement of liposuctioned tissue. Plast Reconstr Surg. 2001;107(2): 595-7.

60. Dennis JE, Esterly K, Awadallah A, Parrish CR, Poynter GM, Goltry KL. Clinicalscale expansion of a mixed population of bone-marrow-derived stem and progenitor cells for potential use in bone-tissue regeneration. Stem Cells. 2007;25(10):2575-82.

61. Rojewski MT, Fekete N, Baila S, Nguyen K, Fürst D, Antwiler D, et al. GMPcompliant isolation and expansion of bone marrow-derived MSCs in the closed, automated device quantum cell expansion system. Cell Transplant. 2013:22(11):1981-2000.

62. Gastens MH, Goltry K, Prohaska W, Tschöpe D, Stratmann B, Lammers D, et al. Good manufacturing practice-compliant expansion of marrow-derived stem and progenitor cells for cell therapy. Cell Transplant. 2007;16(7):685-96.

63. Chen X, Xu H, Wan C, McCaigue M, Li G. Bioreactor expansion of human adult bone marrow-derived mesenchymal stem cells. Stem Cells. 2006;24(9): 2052-9.

64. Dos-Anjos Vilaboa S, Navarro-Palou M, Llull R. Age influence on stromal vascular fraction cell yield obtained from human lipoaspirates. Cytotherapy. 2014;16(8):1092-7. 
65. Brown JC, Shang H, Li Y, Yang N, Patel N, Katz AJ. Isolation of AdiposeDerived Stromal Vascular Fraction Cells Using a Novel Point-of-Care Device: Cell Characterization and Review of the Literature. Tissue Eng Part C Methods. 2017;23(3):125-35.

66. Rose LC, Kadayakkara DK, Wang G, Bar-Shir A, Helfer BM, O'Hanlon CF, et al. Fluorine-19 Labeling of Stromal Vascular Fraction Cells for Clinical Imaging Applications. Stem Cells Transl Med. 2015;4(12):1472-81.

67. Dos-Anjos Vilaboa S, Llull R, Mendel TA. Returning fat grafts to physiologic conditions using washing. Plast Reconstr Surg. 2013;132(2):323e-6e.

68. Doi K, Tanaka S, lida H, Eto H, Kato H, Aoi N, et al. Stromal vascular fraction isolated from lipo-aspirates using an automated processing system: bench and bed analysis. J Tissue Eng Regen Med. 2013;7(11):864-70.

69. Bukowska J, Alarcon Uquillas A, Wu X, Frazier T, Walendzik K, Vanek M, et al. Safety of Human Adipose Stromal Vascular Fraction Cells Isolated with a Closed System Device in an Immunocompetent Murine Pressure Ulcer Model. Stem Cells Dev. 2020;29(7):452-61.

70. Aronowitz JA, Ellenhorn JDI. Adipose stromal vascular fraction isolation: a head-to-head comparison of four commercial cell separation systems. Plast Reconstr Surg. 2013;132(6):932e-9e.

71. Hanke A, Prantl L, Wenzel C, Nerlich M, Brockhoff G, Loibl M, et al. Semiautomated extraction and characterization of Stromal Vascular Fraction using a new medical device. Clin Hemorheol Microcirc. 2016;64(3):403-12.

72. Rada T, Gomes ME, Reis RL. A novel method for the isolation of subpopulations of rat adipose stem cells with different proliferation and osteogenic differentiation potentials. J Tissue Eng Regen Med. 2011;5(8): 655-64.

73. Zuk PA, Zhu M, Ashjian P, De Ugarte DA, Huang Jl, Mizuno H, et al. Human adipose tissue is a source of multipotent stem cells. Mol Biol Cell. 2002; 13(12):4279-95.

74. Zuk PA, Zhu M, Mizuno H, Huang J, Futrell JW, Katz AJ, et al. Multilineage cells from human adipose tissue: implications for cell-based therapies. Tissue Eng. 2001;7(2):211-28.

75. Raposio E, Bonomini S, Calderazzi F. Isolation of autologous adipose tissuederived mesenchymal stem cells for bone repair. Orthop Traumatol Surg Res. 2016;102(7):909-12.

76. Raposio E, Simonacci F, Perrotta RE. Adipose-derived stem cells: Comparison between two methods of isolation for clinical applications. Ann Med Surg (Lond). 2017;20:87-91.

77. Zhang X, Hirai M, Cantero S, Ciubotariu R, Dobrila L, Hirsh A, et al. Isolation and characterization of mesenchymal stem cells from human umbilical cord blood: reevaluation of critical factors for successful isolation and high ability to proliferate and differentiate to chondrocytes as compared to mesenchymal stem cells from bone marrow and adipose tissue. J Cell Biochem. 2011;112(4):1206-18.

78. Dominici M, Le Blanc K, Mueller I, Slaper-Cortenbach I, Marini F, Krause D, et al. Minimal criteria for defining multipotent mesenchymal stromal cells. The International Society for Cellular Therapy position statement. Cytotherapy. 2006:8(4):315-7

79. Mitchell JB, Mclntosh K, Zvonic S, Garrett S, Floyd ZE, Kloster A, et al. Immunophenotype of human adipose-derived cells: temporal changes in stromal-associated and stem cell-associated markers. Stem Cells. 2006;24(2): 376-85.

80. Griesche N, Luttmann W, Luttmann A, Stammermann T, Geiger H, Baer PC. A simple modification of the separation method reduces heterogeneity of adipose-derived stem cells. Cells Tissues Organs (Print). 2010;192(2):106-15.

81. Rada T, Santos TC, Marques AP, Correlo VM, Frias AM, Castro AG, et al. Osteogenic differentiation of two distinct subpopulations of human adipose-derived stem cells: an in vitro and in vivo study. J Tissue Eng Regen Med. 2012;6(1):1-11.

82. Rada T, Reis RL, Gomes ME. Distinct stem cells subpopulations isolated from human adipose tissue exhibit different chondrogenic and osteogenic differentiation potential. Stem Cell Rev. 2011;7(1):64-76.

83. Cuevas-Diaz Duran R, González-Garza MT, Cardenas-Lopez A, Chavez-Castilla L, Cruz-Vega DE, Moreno-Cuevas JE. Age-related yield of adipose-derived stem cells bearing the low-affinity nerve growth factor receptor. Stem Cells Int. 2013;2013:372164

84. Calabrese G, Giuffrida R, Lo Furno D, Parrinello NL, Forte S, Gulino R, et al. Potential Effect of CD271 on Human Mesenchymal Stromal Cell Proliferation and Differentiation. Int J Mol Sci. 2015;16(7):15609-24.

85. Pachón-Peña G, Yu G, Tucker A, Wu X, Vendrell J, Bunnell BA, et al. Stromal stem cells from adipose tissue and bone marrow of age-matched female donors display distinct immunophenotypic profiles. J Cell Physiol. 2011; 226(3):843-51.

86. Bourin P, Bunnell BA, Casteilla L, Dominici M, Katz AJ, March KL, et al. Stromal cells from the adipose tissue-derived stromal vascular fraction and culture expanded adipose tissue-derived stromal/stem cells: a joint statement of the International Federation for Adipose Therapeutics and Science (IFATS) and the International Society for Cellular Therapy (ISCT). Cytotherapy. 2013;15(6):641-8.

87. Czapla J, Matuszczak S, Kulik K, Wiśniewska E, Pilny E, Jarosz-Biej M, et al. The effect of culture media on large-scale expansion and characteristic of adipose tissue-derived mesenchymal stromal cells. Stem Cell Res Ther. 2019;10(1):235

88. Hagmann S, Moradi B, Frank S, Dreher T, Kämmerer PW, Richter W, et al. FGF-2 addition during expansion of human bone marrow-derived stromal cells alters MSC surface marker distribution and chondrogenic differentiation potential. Cell Prolif. 2013;46(4):396-407.

89. Raposio E, Caruana G, Petrella M, Bonomini S, Grieco MP. A Standardized Method of Isolating Adipose-Derived Stem Cells for Clinical Applications. Ann Plast Surg. 2016;76(1):124-6.

90. Haack-Sørensen M, Juhl M, Follin B, Harary Søndergaard R, Kirchhoff M, Kastrup J, et al. Development of large-scale manufacturing of adiposederived stromal cells for clinical applications using bioreactors and human platelet lysate. Scand J Clin Lab Invest. 2018;78(4):293-300.

91. Aijaz A, Li M, Smith D, Khong D, LeBlon C, Fenton OS, et al. Biomanufacturing for clinically advanced cell therapies. Nat Biomed Eng. 2018;2(6):362-76.

92. Haack-Sørensen M, Follin B, Juhl M, Brorsen SK, Søndergaard RH, Kastrup J, et al. Culture expansion of adipose derived stromal cells. A closed automated Quantum Cell Expansion System compared with manual flaskbased culture. J Transl Med. 2016;14(1):319.

93. Lechanteur C, Briquet A, Giet O, Delloye O, Baudoux E, Beguin Y. Clinicalscale expansion of mesenchymal stromal cells: a large banking experience. J Transl Med. 2016;14(1):145.

94. Bieback K, Schallmoser K, Klüter H, Strunk D. Clinical Protocols for the Isolation and Expansion of Mesenchymal Stromal Cells. Transfus Med Hemother. 2008;35(4):286-94.

95. Witzeneder K, Lindenmair A, Gabriel C, Höller K, Theiß D, Redl H, et al. Human-derived alternatives to fetal bovine serum in cell culture. Transfus Med Hemother. 2013:40(6):417-23.

96. Escobar $\mathrm{CH}$, Chaparro O. Xeno-Free Extraction, Culture, and Cryopreservation of Human Adipose-Derived Mesenchymal Stem Cells. Stem Cells Transl Med. 2016;5(3):358-65.

97. Hao L, Sun H, Wang J, Wang T, Wang M, Zou Z. Mesenchymal stromal cells for cell therapy: besides supporting hematopoiesis. Int J Hematol. 2012; 95(1):34-46.

98. Schallmoser K, Bartmann C, Rohde E, Reinisch A, Kashofer K, Stadelmeyer E, et al. Human platelet lysate can replace fetal bovine serum for clinical-scale expansion of functional mesenchymal stromal cells. Transfusion. 2007;47(8): 1436-46.

99. Capelli C, Gotti E, Morigi M, Rota C, Weng L, Dazzi F, et al. Minimally manipulated whole human umbilical cord is a rich source of clinical-grade human mesenchymal stromal cells expanded in human platelet lysate. Cytotherapy. 2011;13(7):786-801.

100. Lange C, Cakiroglu F, Spiess A-N, Cappallo-Obermann H, Dierlamm J, Zander AR. Accelerated and safe expansion of human mesenchymal stromal cells in animal serum-free medium for transplantation and regenerative medicine. J Cell Physiol. 2007;213(1):18-26.

101. Hatlapatka T, Moretti P, Lavrentieva A, Hass R, Marquardt N, Jacobs R, et al. Optimization of culture conditions for the expansion of umbilical cordderived mesenchymal stem or stromal cell-like cells using xeno-free culture conditions. Tissue Eng Part C Methods. 2011;17(4):485-93.

102. Trojahn Kølle S-F, Oliveri RS, Glovinski PV, Kirchhoff M, Mathiasen AB, Elberg $J$, et al. Pooled human platelet lysate versus fetal bovine seruminvestigating the proliferation rate, chromosome stability and angiogenic potential of human adipose tissue-derived stem cells intended for clinical use. Cytotherapy. 2013;15(9):1086-97.

103. D'Esposito V, Passaretti F, Perruolo G, Ambrosio MR, Valentino R, Oriente F, et al. Platelet-Rich Plasma Increases Growth and Motility of Adipose TissueDerived Mesenchymal Stem Cells and Controls Adipocyte Secretory Function. J Cell Biochem. 2015;116(10):2408-18.

104. Cui XD, Gao DY, Fink BF, Vasconez HC, Pu LLQ. Cryopreservation of human adipose tissues. Cryobiology. 2007;55(3):269-78. 
105. Ray SS, Pramanik K, Sarangi SK, Jain N. Serum-free non-toxic freezing solution for cryopreservation of human adipose tissue-derived mesenchymal stem cells. Biotechnol Lett. 2016;38(8):1397-404.

106. Zhang H-T, Chen H, Zhao H, Dai Y-W, Xu R-X. Neural stem cells differentiation ability of human umbilical cord mesenchymal stromal cells is not altered by cryopreservation. Neurosci Lett. 2011;487(1):118-22

107. Haack-Sorensen M, Bindslev L, Mortensen S, Friis T, Kastrup J. The influence of freezing and storage on the characteristics and functions of human mesenchymal stromal cells isolated for clinical use. Cytotherapy. 2007;9(4): 328-37.

108. Casado-Díaz A, Santiago-Mora R, Jiménez R, Caballero-Villarraso J, Herrera C, Torres A, et al. Cryopreserved human bone marrow mononuclear cells as a source of mesenchymal stromal cells: application in osteoporosis research. Cytotherapy. 2008;10(5):460-8.

109. Zanicotti DG, Coates DE. Growing Adipose-Derived Stem Cells Under Serum-Free Conditions. Methods Mol Biol. 2017;1537:439-46.

110. López M, Bollag RJ, Yu JC, Isales CM, Eroglu A. Chemically Defined and Xeno-Free Cryopreservation of Human Adipose-Derived Stem Cells. PLoS One. 2016;11(3):e0152161.

111. Minonzio G, Corazza M, Mariotta L, Gola M, Zanzi M, Gandolfi E, et al. Frozen adipose-derived mesenchymal stem cells maintain high capability to grow and differentiate. Cryobiology. 2014;69(2):211-6.

112. Miyagi-Shiohira C, Kurima K, Kobayashi N, Saitoh I, Watanabe M, Noguchi Y, et al. Cryopreservation of Adipose-Derived Mesenchymal Stem Cells. Cell Med. 2015;8(1-2):3-7.

113. Thirumala S, Gimble JM, Devireddy RV. Cryopreservation of stromal vascular fraction of adipose tissue in a serum-free freezing medium. J Tissue Eng Regen Med. 2010;4(3):224-32.

114. Kw Y, P-M B, F X, Wa A, Jr C, Sz O, et al. Phenotypic and Functional Characterization of Long-Term Cryopreserved Human Adipose-Derived Stem Cells. Sci Rep. 2015; Available from: https://pubmed.ncbi.nlm.nih gov/25872464/?from_term=Yong+KW++\%26+DMSO\&from_pos=2. Cited 2020 May 27.

115. Wolter TP, von Heimburg D, Stoffels I, Groeger A, Pallua N. Cryopreservation of mature human adipocytes: in vitro measurement of viability. Ann Plast Surg. 2005;55(4):408-13.

116. Moscatello DK, Dougherty M, Narins RS, Lawrence N. Cryopreservation of human fat for soft tissue augmentation: viability requires use of cryoprotectant and controlled freezing and storage. Dermatol Surg. 2005; 31(11 Pt 2):1506-10

117. Li B-W, Liao W-C, Wu S-H, Ma H. Cryopreservation of fat tissue and application in autologous fat graft: in vitro and in vivo study. Aesthet Plast Surg. 2012;36(3):714-22.

118. MacRae JW, Tholpady SS, Ogle RC, Morgan RF. Ex vivo fat graft preservation: effects and implications of cryopreservation. Ann Plast Surg. 2004;52(3):2812 discussion 283

119. Badowski MS, Muise A, Harris DT. Long-Term Biobanking of Intact Tissue from Lipoaspirate. J Clin Med. 2019;8(3).

120. Thirumala S, Zvonic S, Floyd E, Gimble JM, Devireddy RV. Effect of various freezing parameters on the immediate post-thaw membrane integrity of adipose tissue derived adult stem cells. Biotechnol Prog. 2005;21(5):1511-24.

121. Sparrow RL, Komodromou H, Tippett E, Georgakopoulos T, Xu W. Apoptotic lymphocytes and CD34+ cells in cryopreserved cord blood detected by the fluorescent vital dye SYTO 16 and correlation with loss of L-selectin (CD62L) expression. Bone Marrow Transplant. 2006;38(1):61-7.

122. Humpe A, Beck C, Schoch R, Kneba M, Horst H-A. Establishment and optimization of a flow cytometric method for evaluation of viability of CD34+ cells after cryopreservation and comparison with trypan blue exclusion staining. Transfusion. 2005;45(7):1208-13.

123. Kokai LE, Traktuev DO, Zhang L, Merfeld-Clauss S, DiBernardo G, Lu H, et al. Adipose Stem Cell Function Maintained with Age: An Intra-Subject Study of Long-Term Cryopreserved Cells. Aesthet Surg J. 2017;37(4):454-63.

124. Radrizzani M, Soncin S, Bolis S, Lo Cicero V, Andriolo G, Turchetto L. Quality Control Assays for Clinical-Grade Human Mesenchymal Stromal Cells: Validation Strategy. Methods Mol Biol. 2016;1416:339-56.

125. Radrizzani M, Soncin S, Lo Cicero V, Andriolo G, Bolis S, Turchetto L. Quality Control Assays for Clinical-Grade Human Mesenchymal Stromal Cells: Methods for ATMP Release. Methods Mol Biol. 2016;1416:313-37.

126. Camilleri ET, Gustafson MP, Dudakovic A, Riester SM, Garces CG, Paradise CR, et al. Identification and validation of multiple cell surface markers of clinicalgrade adipose-derived mesenchymal stromal cells as novel release criteria for good manufacturing practice-compliant production. Stem Cell Res Ther. 2016;7(1):107.

127. Chapoval Al, Ni J, Lau JS, Wilcox RA, Flies DB, Liu D, et al. B7-H3: a costimulatory molecule for T cell activation and IFN-gamma production. Nat Immunol. 2001;2(3):269-74.

128. Suh W-K, Gajewska BU, Okada H, Gronski MA, Bertram EM, Dawicki W, et al. The B7 family member B7-H3 preferentially down-regulates T helper type 1 mediated immune responses. Nat Immunol. 2003;4(9):899-906.

129. Subbanna PKT. Mesenchymal stem cells for treating GVHD: in-vivo fate and optimal dose. Med Hypotheses. 2007;69(2):469-70.

130. Fernández $O$, Izquierdo G, Fernández V, Leyva L, Reyes V, Guerrero M, et al. Adipose-derived mesenchymal stem cells (AdMSC) for the treatment of secondary-progressive multiple sclerosis: A triple blinded, placebo controlled, randomized phase $\mathrm{I} / \mathrm{II}$ safety and feasibility study. PLoS One. 2018;13(5):e0195891.

131. Álvaro-Gracia JM, Jover JA, García-Vicuña R, Carreño L, Alonso A, Marsal S, et al. Intravenous administration of expanded allogeneic adipose-derived mesenchymal stem cells in refractory rheumatoid arthritis (Cx611): results of a multicentre, dose escalation, randomised, single-blind, placebo-controlled phase Ib/lla clinical trial. Ann Rheum Dis. 2017;76(1):196-202.

132. Planat-Benard V, Silvestre J-S, Cousin B, André M, Nibbelink M, Tamarat $\mathrm{R}$, et al. Plasticity of human adipose lineage cells toward endothelia cells: physiological and therapeutic perspectives. Circulation. 2004;109(5): 656-63.

133. Schmelzer E, McKeel DT, Gerlach JC. Characterization of Human Mesenchymal Stem Cells from Different Tissues and Their Membrane Encasement for Prospective Transplantation Therapies. Biomed Res Int. 2019;2019:6376271.

134. Maumus M, Peyrafitte J-A, D'Angelo R, Fournier-Wirth C, Bouloumié A, Casteilla $\mathrm{L}$, et al. Native human adipose stromal cells: localization, morphology and phenotype. Int J Obes. 2011;35(9):1141-53.

135. Hokugo A, Li A, Segovia LA, Yalom A, Rezzadeh K, Zhou S, et al. Development of chemotactic smart scaffold for use in tissue regeneration. Plast Reconstr Surg. 135(5):877e-84e.

136. Laflamme K, Roberge CJ, Pouliot S, D'Orléans-Juste P, Auger FA, Germain L. Tissue-engineered human vascular media produced in vitro by the selfassembly approach present functional properties similar to those of their native blood vessels. Tissue Eng. 2006;12(8):2275-81.

137. Li X, Wang M, Jing X, Guo W, Hao C, Zhang Y, et al. Bone Marrow- and Adipose Tissue-Derived Mesenchymal Stem Cells: Characterization, Differentiation, and Applications in Cartilage Tissue Engineering. Crit Rev Eukaryot Gene Expr. 2018;28(4):285-310.

138. Prigozhina TB, Khitrin S, Elkin G, Eizik O, Morecki S, Slavin S. Mesenchymal stromal cells lose their immunosuppressive potential after allotransplantation. Exp Hematol. 2008;36(10):1370-6.

139. Kunter U, Rong S, Boor P, Eitner F, Müller-Newen G, Djuric Z, et al. Mesenchymal stem cells prevent progressive experimental renal failure but maldifferentiate into glomerular adipocytes. J Am Soc Nephrol. 2007;18(6): 1754-64.

140. Rubio D, Garcia-Castro J, Martín MC, de la Fuente R, Cigudosa JC, Lloyd AC, et al. Spontaneous human adult stem cell transformation. Cancer Res. 2005; 65(8):3035-9.

141. Bajek A, Gurtowska N, Olkowska J, Kazmierski L, Maj M, Drewa T. AdiposeDerived Stem Cells as a Tool in Cell-Based Therapies. Arch Immunol Ther Exp (Warsz). 2016;64(6):443-54.

142. Bernardo ME, Zaffaroni N, Novara F, Cometa AM, Avanzini MA, Moretta A, et al. Human bone marrow derived mesenchymal stem cells do not undergo transformation after long-term in vitro culture and do not exhibit telomere maintenance mechanisms. Cancer Res. 2007;67(19):9142-9.

143. Torsvik A, Røsland GV, Svendsen A, Molven A, Immervoll H, McCormack E, et al. Spontaneous malignant transformation of human mesenchymal stem cells reflects cross-contamination: putting the research field on track - letter. Cancer Res. 2010;70(15):6393-6.

144. Lye KL, Nordin N, Vidyadaran S, Thilakavathy K. Mesenchymal stem cells: From stem cells to sarcomas. Cell Biol Int. 2016;40(6):610-8

145. Chu D-T, Nguyen TT, Tien NLB, Tran D-K, Jeong J-H, Anh PG, et al. Recent Progress of Stem Cell Therapy in Cancer Treatment: Molecular Mechanisms and Potential Applications. Cells. 2020;9(3).

146. Aheget H, Tristán-Manzano M, Mazini L, Cortijo-Gutierrez M, GalindoMoreno P, Herrera C, et al. Exosome: A New Player in Translational Nanomedicine. J Clin Med. 2020;9(8). 
147. Rodriguez RL, Frazier T, Bunnell BA, Mouton CA, March KL, Katz AJ, et al. Arguments for a Different Regulatory Categorization and Framework for Stromal Vascular Fraction. Stem Cells Dev. 2020;29(5):257-62.

148. Leng Z, Zhu R, Hou W, Feng Y, Yang Y, Han Q, et al. Transplantation of ACE2- Mesenchymal Stem Cells Improves the Outcome of Patients with COVID-19 Pneumonia. Aging Dis. 2020;11(2):216-28.

149. Hoffmann M, Kleine-Weber $H$, Schroeder S, Krüger N, Herrler T, Erichsen S, et al. SARS-CoV-2 Cell Entry Depends on ACE2 and TMPRSS2 and Is Blocked by a Clinically Proven Protease Inhibitor. Cell. 2020;181(2):271-280.e8.

150. Zhou P, Yang X-L, Wang X-G, Hu B, Zhang L, Zhang W, et al. A pneumonia outbreak associated with a new coronavirus of probable bat origin. Nature. 2020;579(7798):270-3.

151. Tisoncik JR, Korth MJ, Simmons CP, Farrar J, Martin TR, Katze MG. Into the eye of the cytokine storm. Microbiol Mol Biol Rev. 2012;76(1):16-32.

152. Yi Y, Lagniton PNP, Ye S, Li E, Xu R-H. COVID-19: what has been learned and to be learned about the novel coronavirus disease. Int J Biol Sci. 2020; 16(10):1753-66

153. Elfiky AA. Ribavirin, Remdesivir, Sofosbuvir, Galidesivir, and Tenofovir against SARS-CoV-2 RNA dependent RNA polymerase (RdRp): A molecular docking study. Life Sci. 2020;253:117592.

154. Coronavirus Pandemic Update 37: The ACE-2 Receptor - The Doorway to COVID-19 (ACE Inhibitors \& ARBs). Available from: https://www.youtube. com/watch?v=1vZDVbaRhyM. Cited 2020 May 3.

155. Shetty AK. Mesenchymal Stem Cell Infusion Shows Promise for Combating Coronavirus (COVID-19)- Induced Pneumonia. Aging Dis. 2020;11(2):462-4.

156. Liang B, Liang J-M, Ding J-N, Xu J, Xu J-G, Chai Y-M. Dimethyloxaloylglycinestimulated human bone marrow mesenchymal stem cell-derived exosomes enhance bone regeneration through angiogenesis by targeting the AKT/ mTOR pathway. Stem Cell Res Ther. 2019;10(1):335.

157. Atluri S, Manchikanti L, Hirsch JA. Expanded Umbilical Cord Mesenchymal Stem Cells (UC-MSCS) as a Therapeutic Strategy in Managing Critically III COVID-19 Patients: The Case for Compassionate Use. Pain Physician. 2020; 23(2):E71-83.

158. Mazini L, Rochette L, Amine M, Malka G. Regenerative Capacity of Adipose Derived Stem Cells (ADSCs), Comparison with Mesenchymal Stem Cells (MSCs). Int J Mol Sci. 2019:20(10).

159. Alcayaga-Miranda F, Cuenca J, Khoury M. Antimicrobial Activity of Mesenchymal Stem Cells: Current Status and New Perspectives of Antimicrobial Peptide-Based Therapies. Front Immunol. 2017;8:339.

160. Therapy for Pneumonia Patients ilnfected by 2019 Novel Coronavirus - Full Text View - ClinicalTrials.gov. Available from: https:/clinicaltrials.gov/ct2/ show/NCT04293692. Cited 2020 May 3.

161. Current Status of Cell-Based Therapies for Respiratory Virus Infections: Applicability to COVID-19. - Abstract - Europe PMC. Available from: https:// europepmc.org/article/pmc/pmc7144273. Cited 2020 May 3.

162. Shu L, Niu C, Li R, Huang T, Wang Y, Huang M, et al. Treatment of severe COVID-19 with human umbilical cord mesenchymal stem cells. Stem Cell Res Ther. 2020;11(1):361.

163. Meng F, Xu R, Wang S, Xu Z, Zhang C, Li Y, et al. Human umbilical cordderived mesenchymal stem cell therapy in patients with COVID-19: a phase 1 clinical trial. Signal Transduct Target Ther. 2020;5(1):172.

164. Mesenchymal Stem Cell Treatment for Pneumonia Patients Infected With COVID-19 - Full Text View - ClinicalTrials.gov. Available from: https:// clinicaltrials.gov/ct2/show/NCT04252118. Cited 2020 May 3.

165. Umbilical Cord(UC)-Derived Mesenchymal Stem Cells(MSCs) Treatment for the 2019-novel Coronavirus(nCOV) Pneumonia - Full Text View ClinicalTrials.gov. Available from: https://clinicaltrials.gov/ct2/show/NCT0426 9525. Cited 2020 May 3.

166. Tovar I, Guerrero R, López-Peñalver JJ, Expósito J, Ruiz de Almodóvar JM. Rationale for the Use of Radiation-Activated Mesenchymal Stromal/Stem Cells in Acute Respiratory Distress Syndrome. Cells. 2020;9(9).

167. Al-Ghadban S, Bunnell BA. Adipose Tissue-Derived Stem Cells: Immunomodulatory Effects and Therapeutic Potential. Physiology (Bethesda). 2020;35(2):125-33.

168. Fukui E, Funaki S, Kimura K, Momozane T, Kimura A, Chijimatsu R, et al. Adipose Tissue-Derived Stem Cells Have the Ability to Differentiate into Alveolar Epithelial Cells and Ameliorate Lung Injury Caused by ElastaseInduced Emphysema in Mice. Stem Cells Int. 2019;2019:5179172.

169. Shukla L, Yuan Y, Shayan R, Greening DW, Karnezis T. Fat Therapeutics: The Clinical Capacity of Adipose-Derived Stem Cells and Exosomes for Human Disease and Tissue Regeneration. Front Pharmacol. 2020;11:158.
170. Shetty R, Ghosh A, Honavar SG, Khamar P, Sethu S. Therapeutic opportunities to manage COVID-19/SARS-CoV-2 infection: Present and future. Indian J Ophthalmol. 2020;68(5):693-702.

171. Slamkova M, Zorad S, Krskova K. Alternative renin-angiotensin system pathways in adipose tissue and their role in the pathogenesis of obesity. Endocr Regul. 2016;50(4):229-40.

172. Engeli S, Gorzelniak K, Kreutz R, Runkel N, Distler A, Sharma AM. Coexpression of renin-angiotensin system genes in human adipose tissue. J Hypertens. 1999;17(4):555-60.

173. Pahlavani M, Kalupahana NS, Ramalingam L, Moustaid-Moussa N. Regulation and Functions of the Renin-Angiotensin System in White and Brown Adipose Tissue. Compr Physiol. 2017;7(4):1137-50.

174. Ryan PM, Caplice NM. Is Adipose Tissue a Reservoir for Viral Spread, Immune Activation, and Cytokine Amplification in Coronavirus Disease 2019? Obesity (Silver Spring). 2020;28(7):1191-4

175. Huang J, Lin H, Wu Y, Fang Y, Kumar R, Chen G, et al. COVID-19 in posttransplant patients-report of 2 cases. Am J Transplant. 2020.

176. Aust L, Devlin B, Foster SJ, Halvorsen YDC, Hicok K, du Laney T, et al. Yield of human adipose-derived adult stem cells from liposuction aspirates. Cytotherapy. 2004;6(1):7-14.

177. Schäffler A, Büchler C. Concise review: adipose tissue-derived stromal cells-basic and clinical implications for novel cell-based therapies. Stem Cells. 2007;25(4):818-27

178. Baglioni S, Cantini G, Poli G, Francalanci M, Squecco R, Di Franco A, et al. Functional differences in visceral and subcutaneous fat pads originate from differences in the adipose stem cell. PLoS One. 2012;7(5):e36569.

179. Raposio E, Ciliberti R. Clinical use of adipose-derived stem cells: European legislative issues. Ann Med Surg (Lond). 2017;24:61-4.

180. Commission Directive 2009/120/EC of 14 September 2009 amending Directive 2001/83/EC of the European Parliament and of the Council on the Community code relating to medicinal products for human use as regards advanced therapy medicinal productsText with EEA relevance. :10.

181. Smith R. Directive 2008/104/EC of the European Parliament and of the Council of 19 November 2008. In: Core EU Legislation. London: Macmillan Education UK; 2015. p. 426-9. Available from: http://link.springer.com/10.1 007/978-1-137-54482-7_45. Cited 2019 Apr 22

182. Goh BC, Thirumala S, Kilroy G, Devireddy RV, Gimble JM. Cryopreservation characteristics of adipose-derived stem cells: maintenance of differentiation potential and viability. J Tissue Eng Regen Med. 2007;1(4):322-4.

\section{Publisher's Note}

Springer Nature remains neutral with regard to jurisdictional claims in published maps and institutional affiliations. 